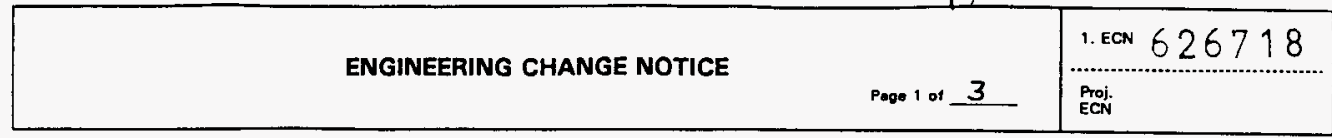

\begin{tabular}{|c|c|c|c|c|c|}
\hline \multirow{3}{*}{$\begin{array}{l}\text { 2. ECN Category } \\
\text { (mark one) } \\
\text { Supplemental } \\
\text { Dirett Revision } \\
\text { Change ECN } \\
\text { Temporary } \\
\text { Standby } \\
\text { Supersedure } \\
\text { Cancel/Noid }\end{array}$} & \multicolumn{2}{|c|}{$\begin{array}{l}\text { 3. Originator's Name, Organization, MSIN, } \\
\text { and Telephone No. } \\
\text { C. T. Sadanaga, IS\&FP Programs, } \\
\text { B1-10, 372-1378 }\end{array}$} & \multicolumn{2}{|c|}{$\begin{array}{l}\text { 3a. USQ Required? } \\
\text { [] Yes }[\mathrm{x}] \text { No }\end{array}$} & $\begin{array}{l}\text { 4. Date } \\
\text { July 3, } 1996\end{array}$ \\
\hline & \multicolumn{2}{|c|}{$\begin{array}{l}\text { 5. Project Title/No./Work order No. } \\
\text { SNF CSB Project W- } 379\end{array}$} & \multicolumn{2}{|c|}{$\begin{array}{l}\text { 6. Bldg./Sys./Fac. No. } \\
\text { CSB }\end{array}$} & $\begin{array}{c}\text { 7. Approval Desi } \\
\text { ESQ }\end{array}$ \\
\hline & \multicolumn{2}{|c|}{$\begin{array}{l}\text { 8. Document Numbers Changed by this ECN } \\
\text { (includes sheet no. and rev.) } \\
\text { WHC-SD-SNF-FHA-002, Rev. } 0\end{array}$} & \multicolumn{2}{|c|}{$\begin{array}{l}\text { 9. Related ECN No(s). } \\
\text { N/A }\end{array}$} & 10. Related PO No. \\
\hline \multirow{2}{*}{$\begin{array}{l}\text { 11a. Modification Work } \\
\text { [] res (fill out Blk. } \\
11 \mathrm{~b}) \\
\text { [X] No (NA Blks. 11b, } \\
11 \mathrm{c}, 11 \mathrm{~d} \text { ) }\end{array}$} & \multirow[t]{2}{*}{$\begin{array}{l}\text { 11b. Hork Package } \\
\text { No. } \\
\text { N/A }\end{array}$} & \multicolumn{2}{|c|}{$\begin{array}{l}\text { 11c. Modification Work Complete } \\
\text { N/A }\end{array}$} & \multicolumn{2}{|c|}{$\begin{array}{l}\text { 11d. Restored to Original Condi- } \\
\text { tion (Temp. or Standby ECN only) } \\
\text { N/A }\end{array}$} \\
\hline & & Cog. Engineer sig & & & \\
\hline
\end{tabular}

12. Description of Change

Revise WHC-SD-SNF-FHA-002 by replacing Revision 0, which was limited to the Storage

Vault area, with attached Revision 1, which addresses the entire facility.

EDT was inadvertently used. Signatures are on Page 3 of 3

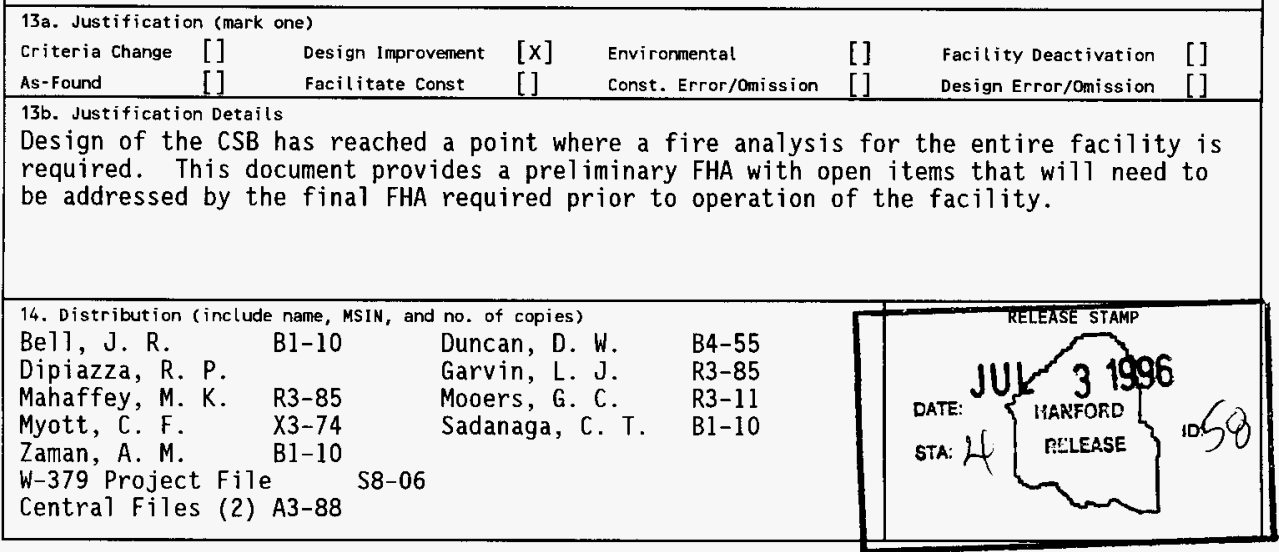

A-7900-013-2 (11/94) GEF095 


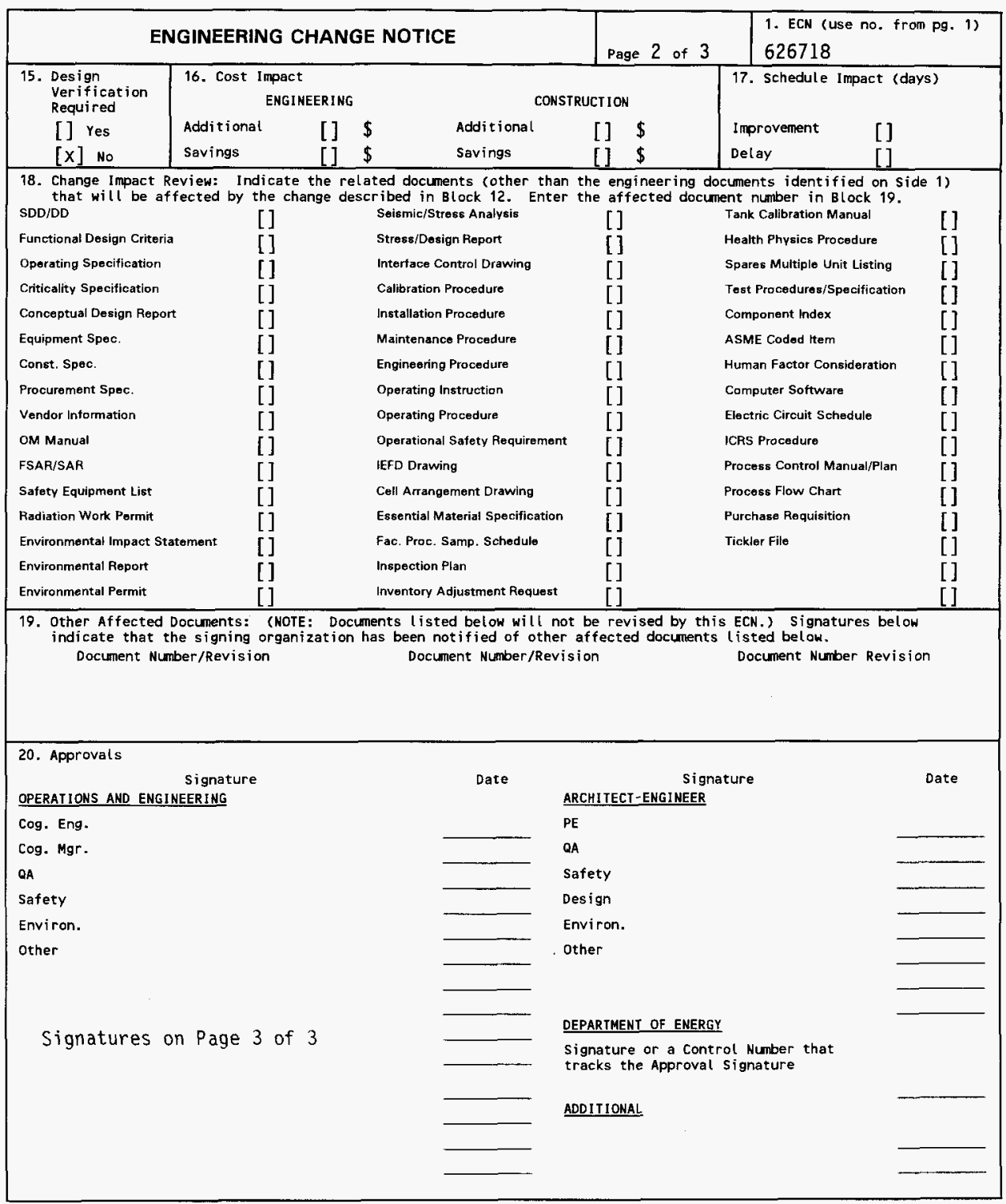




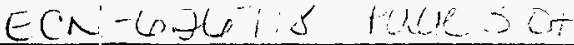

ENGINEERING DATA TRANSMITTAL

2. To: (Receiving Organization)

SNF CSB Project

5. Proj./Prog./Dept./Div.:

SNF CSB Project W-379

8. Originator Remarks:

Distribution for approval.

11. Receiver Remarks:
3. From: (Originating Organization) Fire Protection Programs

6. Cog. Engr.:

C. T. Sadanaga
4. Related EDT No.:

140024

7. Purchase Order No.:

NA

9. Equip./Component No.:

NA

10. System/Bldg./Facility:

SNF /CSB

12. Major Assm. Owg. No.:

NA

13. Permit/Permit Application No.: NA

14. Required Response Date:

$6 / 28 / 96$

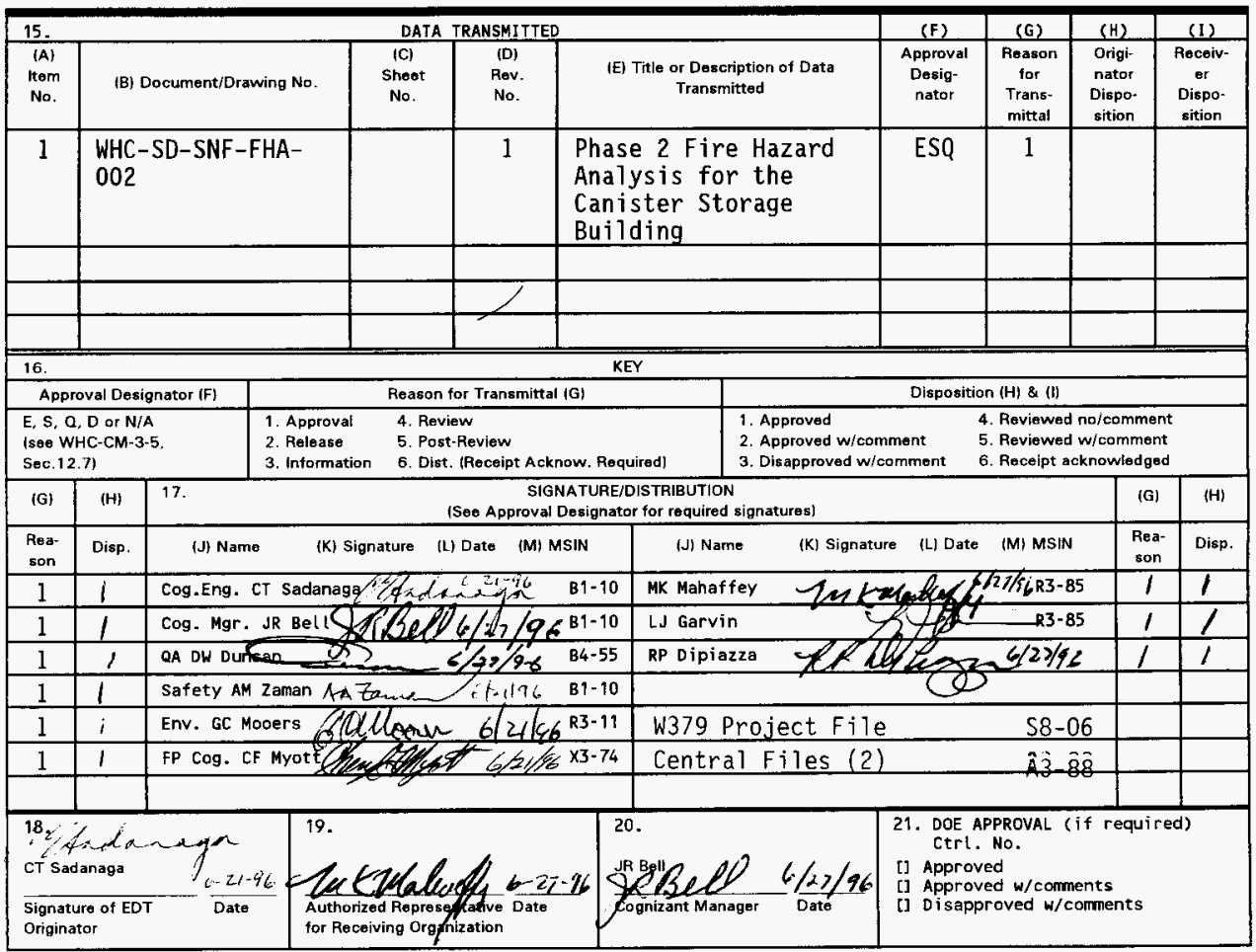




\section{Phase 2 Fire Hazard Analysis for the Canister Storage Building}

\section{T. Sadanaga}

Westinghouse Hanford Company, Richland, WA 99352

U.S. Department of Energy Contract DE-ACO6-87RL10930
EDT/ECN: 615152
UC: 620
Org Code: $31 \mathrm{B00}$
B\&R Code: EW3135040
Charge Code: 16022 towal Pages: $54 / 96$

Key Words: Fire Hazard Analysis, FHA, CSB

Abstract: The fire hazard analysis assesses the risk from fire in a facility to ascertain whether the fire protection policies are met. This document provides a preliminary FHA for the CSB facility. Open items have been noted in the document. A final FHA will be required at the completion of definitive design, prior to operation of the facility.

FASTLite is a Registered Trademark of National Institute of Standards and Technologies

FPETOOL is a Registered Trademark of National Institute of Standards and Technologies

VESDA is a Registered Trademark of I.E.I. (North America, Inc.)

TRADEMARK DISCLAIMER. Reference herein to any specific commercial product, process, or service by trade name, trademark, manufacturer, or otherwise, does not necessarily constitute or imply its endorsement, recommendation, or favoring by the United States Goverment or any agency thereof or its contractors or subcontractors.

Printed in the United States of America. To obtain copies of this document, contact: WHC/BCS Document Control Services, P.O. Box 1970, Mailstop H6-08, Richland WA 99352, Phone (509) 372-2420 Fax (509) 376-4989.
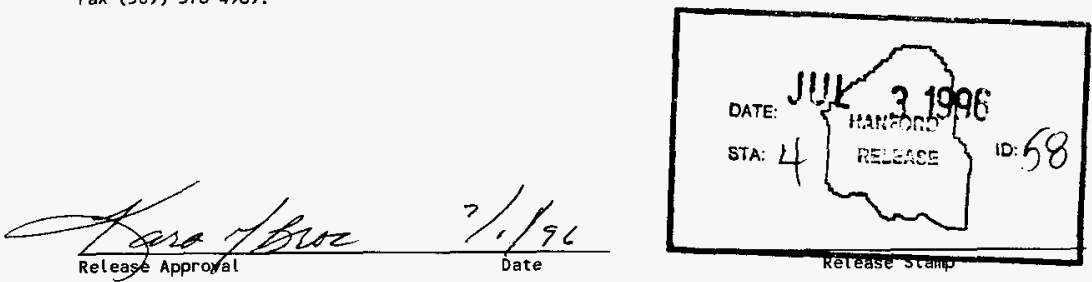

\section{Approved for Public Release}




\section{RECORD OF REVISION}

(1) Document Number

WHC-SD-SNF-FHA002

(2) Iitle

Fire Hazard Analysis for the Canister Storage Building

CHANGE CONTROL RECORD

\begin{tabular}{|c|c|c|c|c|}
\hline & \multirow{2}{*}{ Revision } & \multirow{2}{*}{ (4) Description of Change - Replace, Add, and Delete Pages } & \multicolumn{2}{|c|}{ Authorized for Release } \\
\hline & & & (5) Cog. Engr. & (6) Cog. Mgr. \\
\hline & 0 & $\begin{array}{l}\text { Initial Issue -- EDT 140024, Released } \\
3 / 5 / 96\end{array}$ & YAadanou & Damen woyl/ $7 / 3 / 96$ \\
\hline RS & 1 & $\begin{array}{l}\text { Replace entire document with Revision } 1 . \\
\text { Approved by ECN } 626718 \text {. }\end{array}$ & Thadarag & Comitan Bed $7 / 3 / 46$ \\
\hline & & & f & \\
\hline & & & & \\
\hline & & & & \\
\hline & & & & \\
\hline & & & & \\
\hline & & & & \\
\hline & & & & \\
\hline & & & & \\
\hline & & & & \\
\hline & & & & \\
\hline & & & & \\
\hline & & & & \\
\hline & & & & \\
\hline & & & & \\
\hline & & & & \\
\hline & & & & \\
\hline & & & & \\
\hline & & & & \\
\hline & & & & \\
\hline & & & & \\
\hline & & & & \\
\hline & & & & \\
\hline & & & & \\
\hline & & & & \\
\hline & & & & \\
\hline
\end{tabular}


WHC-SD-SNF-FHA-002, REV. 1

PHASE 2

FIRE HAZARD ANALYSIS

FOR THE

CANISTER STORAGE BUILDING

Westinghouse Hanford Company

June 1996

Prepared by

C. T. Sadanaga

Fire Protection Programs 
WHC-SD-SNF-FHA-002, REV. 1

THIS PAGE LEFT BLANK 
WHC-SD-SNF-FHA-002, REV. I

TABLE OF CONTENTS

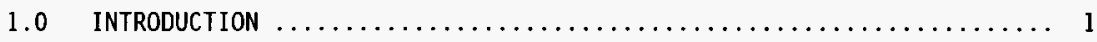

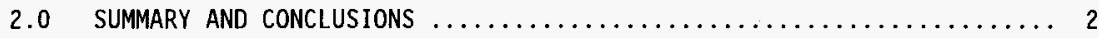

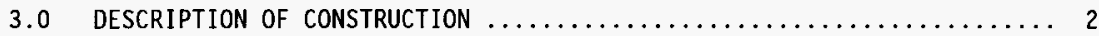

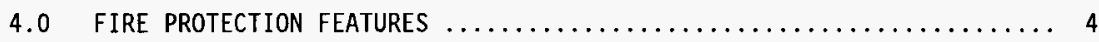

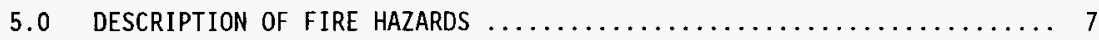

6.0 PROTECTION OF ESSENTIAL SAFETY CLASS SYSTEMS $\ldots \ldots \ldots \ldots \ldots \ldots \ldots, 9$

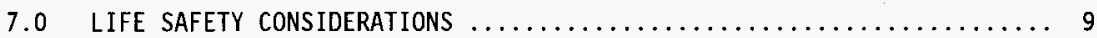

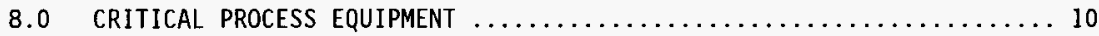

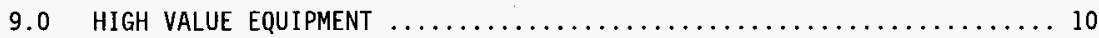

10.0 DAMAGE POTENTIAL: $\ldots \ldots \ldots \ldots \ldots \ldots \ldots \ldots \ldots \ldots \ldots \ldots \ldots \ldots \ldots \ldots \ldots \ldots \ldots \ldots \ldots \ldots \ldots$

10.1 DESCRIPTION $\ldots \ldots \ldots \ldots \ldots \ldots \ldots \ldots \ldots \ldots \ldots \ldots \ldots \ldots \ldots \ldots \ldots \ldots \ldots \ldots$

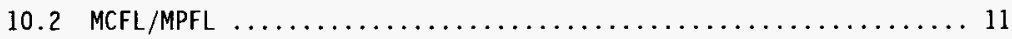

11.0 FIRE DEPARTMENT/BRIGADE RESPONSE $\ldots \ldots \ldots \ldots \ldots \ldots \ldots \ldots \ldots \ldots \ldots \ldots \ldots \ldots$

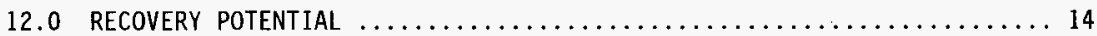

13.0 POTENTIAL FOR A TOXIC, BIOLOGICAL AND $/ 0 R$
RADIATION INCIDENT DUE TO A FIRE $\ldots \ldots \ldots \ldots \ldots \ldots \ldots \ldots \ldots \ldots \ldots \ldots \ldots \ldots \ldots$

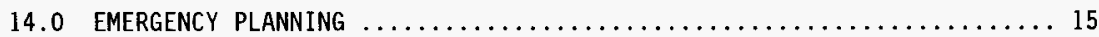

15.0 SECURITY AND SAFEGUARDS CONSIDERATIONS

16.0 NATURAL HAZARDS IMPACT ON FIRE SAFETY $\ldots \ldots \ldots \ldots \ldots \ldots \ldots \ldots \ldots \ldots \ldots \ldots \ldots$

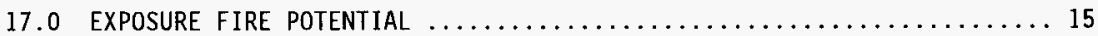

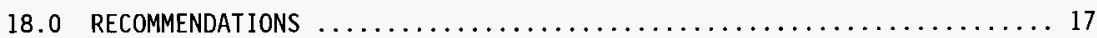

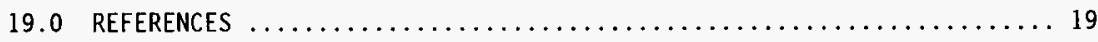

FIGURE 1. MCO AND CUT-AWAY VIEW OF VAULT $1 \ldots \ldots \ldots \ldots \ldots \ldots \ldots \ldots \ldots \ldots$ 
WHC-SD-SNF-FHA-002, REV. 1

FIGURE 2. CUT-AWAY VIEW OF CSB SHOWING

FUTURE PROPOSED LOCATION OF HVCF

FIGURE 3. CUT-AWAY VIEW OF VAULT 1 SHOWING

VENTILATION INTAKE STRUCTURE AND EXHAUST STACK

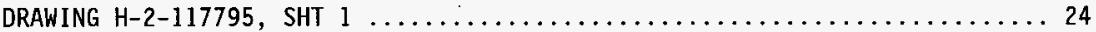

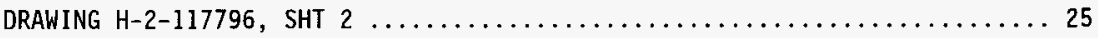

APPENDIX A - DESCRIPTION OF STAGING/STORAGE PROCESS $\ldots \ldots \ldots \ldots \ldots \ldots \ldots \ldots 27$

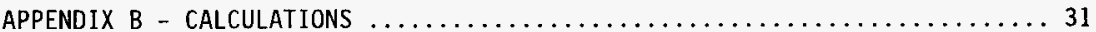




\section{WHC-SD-SNF-FHA-002, REV. 1 \\ ACRONYMS}

$\begin{array}{ll}\text { CSB } & \text { Canister Storage Building } \\ \text { DCS } & \text { Digital Collection System } \\ \text { DOE } & \text { U. S. Department of Energy } \\ \text { FHA } & \text { Fire Hazard Analysis } \\ \text { HEPA } & \text { High-Efficiency Particulate Air } \\ \text { HFD } & \text { Hanford Fire Department } \\ \text { HPS } & \text { Health Protection System } \\ \text { HVCF } & \text { Hot Vacuum Conditioning Facility } \\ \text { MCO } & \text { Multi-canister Overpack } \\ \text { MCFL } & \text { Maximum Credible Fire Loss } \\ \text { MHM } & \text { MCO Handling Machine } \\ \text { MPFL } & \text { Maximum Possible Fire Loss } \\ \text { RFAR } & \text { Radio Fire Alarm Reporter } \\ \text { SNF } & \text { Spent Nuclear Fuel }\end{array}$


WHC-SD-SNF-FHA-002, REV . I

THIS PAGE LEFT BLANK 


\subsection{INTRODUCTION}

A Fire Hazard Analysis (FHA) is required for all new facilities. The Spent Nuclear Fuel Canister Storage Building (SNF CSB) facility is a non-reactor nuclear facility being constructed in the 200 East Area. Multi-canister overpacks (MCO), filled with K Basin SNF, will be received by the CSB for short-term staging (6 years or less) until processed at the Hot Vacuum Conditioning Facility (HVCF). If the SNF is processed in the conditioning facilities, the CSB will be re-configured for interim storage of the MCOS until their final disposition has been determined. A description of the storage process is summarized in Appendix A.

The FHA was prepared in accordance with DOE 5480.7A, Fire Protection, (DOE 1993) and WHC-CM-4-41, Fire Protection Program Manua7 (WHC-CM-4-41), Section 3.4, "Fire Hazards Analys is." WHC-CM-4-4l implements DOE 5480.7A and includes guidance provided by DOE on the performance of FHAs. The analysis evaluates the potential fire risks to determine if any undue hazards require mitigation to protect employees, property, the public, or the environment. The specific objectives of DOE $5480.7 \mathrm{~A}$ include the following:

1. Minimize the potential for the occurrence of a fire.

2. Ensure that fire does not cause an onsite or offsite release of radiological and other hazardous material that will threaten the public health and safety or the environment.

3. Establish requirements that will provide an acceptable degree of 1 ife safety to DOE and contractor personnel and ensure that there are no undue hazards to the public from fire and its effects in DOE facilities.

4. Ensure that vital DOE programs will not suffer unacceptable delays as a result of fire and related perils.

5. Ensure that property damage from fire and related perils does not exceed an acceptable level.

6. Ensure that process control and safety systems are not damaged by fire or related perils.

WHC-SD-SNF-FHA-002, Phase 1 Fire Hazard Analysis for the Canister Storage Building Storage Vault (WHC 1996a), addressed the below ground structure. This FHA will address the entire structure and operation based on approximately $50 \%$ of the Definitive Design. The purpose of this FHA is to identify any conditions that may have design impacts. If design or operational conditions beyond the limits established by the identified project documentation are proposed, further evaluation of the risks involved is required and shall be documented in a revised FHA. 
WHC-SD-SNF-FHA-002, REV. 1

\subsection{SUMMARY AND CONCLUSIONS}

A basic assumption is that if a hydrogen burn event were to occur, release of the larger radionuclide particles will be confined within the facility and only the minute particles that will be widely dispersed will be released. Releases will need to be within the exposure limits for onsite and offsite receptors. This issue is still being studied. Concerns regarding the control of the hydrogen hazard are the subject of Finding/Recommendation 2 in Section 18.0 of the document.

The threat to the MCOs from an external fire source is very low. The facility is of noncombustible construction and of low combustible loading, especially in the Operating Area. Finding/Recommendation 1 and 3 through 5 address noncompliances with requirements that will require system upgrades or submission and approval of an equivalency or exemption.

\subsection{DESCRIPTION OF CONSTRUCTION}

The CSB consists of two adjoining areas: the Operating Area and the operations Support Area. Both areas were designated by the project as Type II-N construction with a Uniform Building Code (UBC) occupancy classification of Group F, Division $2(\mathrm{~F}-2)$. The FHA considers a Group H, Division $7(\mathrm{H}-7)$ to be more appropriate for the Operating Area due to the potential for hazardous radioactive material release. A reclassification would entail additional fire protection features required by the code including sprinklers and possibly upgrading the construction to a Type II-1 hour. The additional fire protection features would add little benefit with regard to fire or radiological safety. (Finding/Recommendation 1)

The operating Area is a structural steel building with insulated metal walls. The building encloses three below grade reinforced concrete vaults covered with a $5 \mathrm{ft}$ thick concrete slab operating deck, the load-in/load-out area, and the truck vestibule. The building is approximately $205 \mathrm{ft}$ by $135 \mathrm{ft}$ by $55 \mathrm{ft}$ high. See Drawing H-2-117795/1.

The Storage Vault Area (approximately $29,700 \mathrm{ft}^{2}$ ) consists of three concrete vaults (approximately $48 \mathrm{ft}$ deep) separated by concrete walls. Vault 1 will house 220 stee 1 MCO storage tubes with six overpack storage tubes. Each steel tube will hold two MCOs stacked two-high. The tubes are supported by the floor and are closed and sealed by means of a shielded plug installed at the operating deck level. Tube plug covers installed over the plugs provide protection of the plug and provide a flat deck surface. There is no communication between the space inside the tube and the vault. The capability to use the six overpack storage tubes is not presently available. Vaults 2 and 3 will not have storage tubes nor plugs but will be provided with tube plug covers at the surface operating deck. 
Natural convection cooling will be provided to the vaults to cool the SNF stored within the MCOs. Outside air will be drawn into the vault area by buoyancy forces due to the density difference between the hot air inside the vault and the cooler air outside. Air will be drawn in through an elevated intake structure and exhausted through an elevated stack. Each vault will be provided with its own intake and exhaust structure. Contamination from the MCOs will be contained within the tubes and not enter the vault atmosphere, therefore, High-Efficiency Particulate Air (HEPA) filtration of the vault ventilation system is not required. See Figures 1,2 , and 3 .

The Operating Deck (approximately 26,000 $\mathrm{ft}^{2}$ ) is approximately $5 \mathrm{ft}$ thick reinforced concrete. An $3 \mathrm{ft}$ high concrete curb surrounds the deck boundary. Floor embeds in which the shielded plugs are supported are built into the deck. The embeds are designed with a bellows barrier that isolates the vault space from the operating deck space. A double o-ring seal arrangement isolates the tube space from the operating deck space. A pressure of approximately $8 \mathrm{psi}$ is required to lift the plug thereby failing the confinement provided by the plug and storage tubes. The concrete plug is provided with the capability to monitor, vent, and purge the tube space. The MCO Handling Machine (MHM) gantry crane provides MCO hoisting coverage over the Operating and Load-in/Load-out Areas.

The Truck Vestibule (approximately 2,000 $\mathrm{ft}^{2}$ ) and Load-in/Load-out Area (approximately 2,300 $\mathrm{ft}^{2}$ ) have a concrete slab foundation and includes the MCO Service Station. The MCO Service Station is a pit into which the shipping cask containing the MCO will be inserted for MCO servicing prior to staging. Radiation shielding is provided by concrete and stee1. A receiving gantry crane is provided to hoist loads within these areas.

The Operations Support Area is also a structural steel building with a concrete slab foundation, insulated metal exterior walls, and gypsum board interior walls. This building houses the Control Room, Change Rooms, and electrical and mechanical equipment. The building is approximately $54 \mathrm{ft}$ by $150 \mathrm{ft}$ by $17 \mathrm{ft}$ high. The metal wall system consists of insulating material sandwiched between an exterior metal panel and an interior metal 1 iner panel. The roofing for both buildings is membrane roofing on rigid insulation with protective board on a metal deck supported by the structural steel frame. The Operations Support Area is separated from the Operating Area by a two-hour fire rated wa11. See Drawing 117796/1.

The Operations Support Area (approximately $8,000 \mathrm{ft}^{2}$ ) contains non-1oadbearing interior gypsum board walls. Doors, hardware, and trim are standard building products. The regulated area is provided with a grille panel access floor to contain potentially contaminated water runoff from a sprinkler discharge. The Control Room has a raised panel floor for cable runs. HVAC equipment, electrical panels, and standby generators are located in separate rooms. 
WHC-SD-SNF-FHA-002, REV. 1

The two Standby Generator Rooms (approximately $290 \mathrm{ft}^{2}$ each) will each contain a standby generator, a fuel day-tank, and associated piping and panels. The rooms will be constructed to meet a two-hour fire resistive rating to provide separation of the hazard from the fuel from the remainder of the Operations Support Area.

\subsection{FIRE PROTECTION FEATURES}

Hydrogen Hazard Mitigation. Generation of hydrogen from the MCOs is assumed to occur during the various stages from delivery of the MCOs to the CSB to the "staging" mode as the MCOS are awaiting hot vacuum conditioning. The current method of hydrogen hazard mitigation being considered is three-fold:

1) control the generation rate, 2) minimize the accumulation of hydrogen, and

3) provide an inert helium atmosphere that would preclude or limit the severity of a reaction even in the presence of a flammable concentration of hydrogen.

Studies of the hydrogen issue are still ongoing. WHC-SD-SNF-RPT-004, Spent Nuclear Fuel Project, Canister Storage Building Safety Analysis Report Phase 2, Safety Analysis Document Supporting Canister Storage Building Subsurface and Operating Deck Construction, (WHC 1996b), has demonstrated that release of a fraction of the MCO inventory, as may occur with a hydrogen burn event or other event that could overpressurize the confinement boundary, has the potential for requiring safety class equipment to reduce the probability of the event or to mitigate the event consequences. Besides the consequence of exposure of personnel to radionuclides, contamination cleanup criteria would al so need to be addressed. If a release from a hydrogen burn event were to occur, the fire losses, primarily from cleanup of the 0perating Area, can exceed $\$ 1$ million as discussed in Section 10.2. (Finding/Recommendation 2) Installation of a sprinkler system would not mitigate the consequences from a hydrogen burn event. Described below are the methods under consideration for the various MCO activities to preclide a hydrogen burn event.

A MCO delivered to the CSB is positioned in the MCO Service Station. A tent is placed over the station for contamination confinement and control. The MCO is connected to the MCO Servicing System via a quick-connect fitting. The MCO is depressurized through a HEPA filter and sampling assembly before being exhausted into the tent atmosphere. The tent space is maintained at a sight negative pressure by its own ventilation system. The tent atmosphere is exhausted to the Operating Area through a HEPA filter. Dilution will be used to maintain the concentration of vented hydrogen below flammable limits. The MCO will be purged and inerted at the service station prior to transfer to a storage tube for staging.

During transfer of the vented MCO from the MCO Service Station to the storage tube, hydrogen will continue to be generated in the MHM. The MHM will be actively ventilated with inert gas during transfer evolutions which will reduce the chances of air inleakage and accumulation of hydrogen in quantities that could support a hydrogen burn. The hydrogen production rate is still 
under study, however, accumulation of hydrogen to flammable concentrations is not anticipated under these conditions.

During staging of the MCOs in the storage tubes, hydrogen gas will be generated and permitted to vent from the MCOs into the sealed storage tubes. The hydrogen generation rate is primarily dependent on temperature and moisture. Cold vacuuming prior to staging will remove most of the moisture. A spent fuel temperature of $400^{\circ} \mathrm{F}$ was determined to provide a safe margin to preclude fuel ignition. This temperature will also preclude accelerated chemical reaction of the fuel and increased gas generation. The natural convection ventilation system was determined to be able to maintain the MCO skin temperature below $270^{\circ} \mathrm{F}$ which will maintain the spent fuel temperature below $400^{\circ} \mathrm{F}$.

The tube atmosphere will be inerted and maintained at a slightly positive pressure of $4 \mathrm{psi}$ or less to preclude ingress of air thereby limiting a reaction even in the presence of hydrogen and an ignition source. Periodic monitoring of the tube space for pressure and hydrogen concentration will be required. Depressurization, purging, and reinerting will be performed based on the monitored parameters. A hydrogen burn in the tube will be precluded by these controls on hydrogen accumulation and oxygen ingress.

Following hot vacuum conditioning, the MCOs will be purged, backfilled with an inert gas, and seal welded prior to being returned to the storage tubes. The MCOs wi11 be interim stored in this condition. Assurance of the noncombustible atmosphere within the sealed MCOs following hot vacuum conditioning is based on the removal of chemically bound water and decomposition of uranium hydride by exposing the MCOs to approximately $570^{\circ} \mathrm{F}$ under vacuum. A passivation step that involves addition of a controlled amount of oxygen to the MCO to oxidize any remaining highly reactive surfaces may be added. The oxygen gettering capacity of the uranium and MCO component material to reduce the internal oxygen levels effectively to zero and an effective MCO closure seal would be the basis for a noncombustible atmosphere within the MCO, regardless of how much hydrogen is generated.

There is a possibility that seal welding will not be possible and that the MCOs will need to remain vented. A study of the seal welding issue is being performed. If the study determines that MCOs will not be able to be seal welded and other features or operations will be required to address hydrogen generation during interim storage, then evaluation of the risks involved with the changed condition will need to be performed.

Fire Barriers. The Operating Area and the Operations Support Area are separated by a two-hour fire rated wa11. The wall is a combination of concrete construction up to a height of about 8 feet with the remainder constructed of gypsum board.

The two Generator Rooms are provided with two-hour fire rated gypsum board walls. The fire rating is sufficient to contain a fire involving 40 gallons 
WHC-SD-SNF-FHA-002, REV. 1

of fuel oil from the day tank located within each room. The calculation was conservatively performed for a 100 gallon tank. (See Appendix B, Calculation 1)

RLID 5480.7 requires compliance with the fire protection requirements of DOE Standard Filter Plenum Fire Protection, DOE-STD-XXXX-95, Proposed (DOE 1995a). The standard is applicable when HEPA type filters serve as the final means of effluent cleaning in a nuclear air cleaning ventilation system. The standard specifies fire rated separation, detection, and sprinklers requirements for the appropriate particular hazards within the building. These features have not been provided in the current design of the filter room. The requirement for fire rated separation of the HEPA filter is intended to prevent an exposing fire from involving the HEPA filter housing and causing an unmitigated release. The construction of the Operations Support Area is designated Type II-N. A two-hour rated enclosure would ensure the integrity of the filter housing from exposure from a fire involving the expected combustible loading in the area adjacent to the filter room. The installed sprinkler system in the 0perations Support Area will also mitigate fire consequences. A fire that would assault the filters directly through the exhaust flow would need to originate in the Operating Area. A fire damper will be installed at the inlet duct to the building filtration system at the two-hour wall separating the 0perating Area from the Operations Support Area. DOE-RL approval of a deviation from the requirements of the Filter Plenum standard will be required if the applicable features are not provided. (Finding/Recommendation 3)

Detection and Alarm System. The fire alarm system is designed in accordance with NFPA 72, National Fire Alarm Code, (NFPA 1993). The fire alarm features will include transmission of signals to the Hanford Fire Department (HFD) via a RFAR; annunciation of separate and distinct fire, supervisory and trouble alarms; annunciation of local building fire alarms; and shutdown of appropriate HVAC units initiate upon receipt of an alarm.

All areas of the facility will be automatically monitored for fire/smoke. Smoke detectors will be installed in the return air ducts of the facility ventilation systems. The Operating Area will be provided with a VESDA air sampling smoke detection system. Manual pull stations will be provided at the exits.

Audible and visual alarm annunciating devices will be appropriately located for occupant notification of a fire condition.

Sprink1ers. Sprinklers will be provided throughout the Operations Support Area in accordance with NFPA 13, Standard for the Installation of Sprinkler Systems (NFPA 1994a). The system will be a wet pipe system hydraulically designed for an Ordinary hazard, Group 2, classification with a density of $0.2 \mathrm{gpm}$ over the most remote $2000 \mathrm{ft}^{2}$.

WHC-S-0425, CSB Performance Specification (WHC 1996c) states that a sprinkler system will not be allowed above the operational deck. The reason for this 
WHC-SD-SNF-FHA-002, REV. 1

requirement is to reduce the potential for moisture entering into the tube space as may be expected if a sprinkler system located in the deck area were to actuate. Moisture in the tube space is thought to increase the possibility of moisture reaching the MCO. A primary purpose of conditioning the MCOs prior to staging was moisture removal to minimize the rate of hydrogen generation.

DOE 5480.7A requires an automatic suppression system to be provided (1) in al1 new structures with an area over 5,000 square feet and (2) in all structures having a maximum possible fire loss (MPFL) in excess of $\$ 1.0$ million or where the maximum credible fire will result in the loss of use of a vital structure for an unacceptable period. Although there are several pieces of equipment in the Operating Area valued at over $\$ 1$ million, the combustible loading on the equipment and to which the equipment may be exposed is insufficient to cause a total loss. Transient combustibles would need to be administratively controlled. (Finding/Recommendation 4) Fire damage to the equipment and facility is not expected to exceed $\$ 1.0$ million from an external fire. However, if a hydrogen burn were to occur that resulted in radionuclide release, the losses from this event will exceed $\$ 1.0$ million.

The minimal fire loss risk of not providing sprinklers in an area with limited fire loading is offset by the improved hydrogen generation risk resulting from elimination of a potential moisture source. An exemption from the DOE 5480.7A requirements is required if a sprinkler system is not to be installed in the operating Area. (Finding/Recommendation 5)

Water Supply. Water will be provided to the CSB sprinkler system via a new 6 inch line tapped off a new 10 inch leg tapped off an existing 12 inch raw water line. The 12 inch line is looped however only one supply to the loop is provided. DOE 6430.1A, General Design Criteria (DOE 1989), Section 1530-99.0, requires a minimum of two reliable, independent sources of water. The best option to meet this requirement appears to be activation of the existing fire pumps and water storage tank located north of the CSB into the raw water loop. (Finding/Recommendation 6)

At least two fire hydrants will be provided within 300 feet of the CSB in accordance with DOE 6430.1A.

Portable Fire Extinguishers. Portable fire extinguishers of the appropriate size and class will be located in the facility in accordance with the criteria of NFPA 10, Standard for Portable Fire Extinguishers (NFPA 1994b). Portable fire extinguishers will also be installed on the Tube Vent and Purge Carts.

\subsection{DESCRIPTION OF FIRE HAZARDS}

The following potential fire hazards were identified. As the project nears its final design, the staging/storing process and combustible loading should be reviewed to determine if the final design is bounded by the hazards evaluated here. 
WHC-SD-SNF-FHA-002, REV. 1

SNF Ignition. The lower ignition temperature for corroded or irradiated fuel is approximately $527^{\circ} \mathrm{F}$. Heat can be generated from the corrosion reaction and from radiolytic decay. The spent fuel temperature will be maintained at a maximum temperature of $400^{\circ} \mathrm{F}$ by the natural convection ventilation system.

Hydrogen. Corrosion of the fuel element generates hydrogen. Hydrogen will be generated until the MCOs are hot vacuum conditioned which will remove chemically bound water and cause any uranium hydride to decompose and release hydrogen from the fuel. High temperature will accelerate the chemical reaction of the fuel. Additionally, at elevated temperatures chemically bound water would be released and residual free water would vaporize allowing reaction with the fuel to further increase temperatures. A hazard exists when hydrogen accumulates in concentrations exceeding the lower flammable limit of $4 \%$. This condition can exist when delays cause a MCO to be confined for an extended period. Examples of when this condition could potentially exist are 1) with in the MCO if shipment from the 100 Area to the CSB MCO Service Station is delayed, 2) within the MCO and MHM if transport from the MCO Service Station to the vault storage tube is delayed and the space is not ventilated with inert gas, and 3 ) within the vault storage tube during staging if the tube atmosphere is not periodically purged.

Fuel 0il. Fuel oil is present in the facility in 40 gallon double-shell day tanks for each of the two diesel generators. Each generator and day tank is located in a room separated from the rest of the Operations Support Area and each other by 2-hour fire rated walls. These rooms, as well as the remainder of the Operations Support Area, are provided with an automatic sprinkler system. The day tanks will be fed from two 500 gallon double-shell tanks located outside the facility. The installation shall meet the requirements of NFPA 30, Flammab7e and Combustible Liquids Code, (NFPA 1993c).

Fuel oil will also be present at the facility in the MCO cask delivery vehicle. The transport trailer will be backed into the truck vestibule and uncoupled. Wheel stops will be provided in the Truck Vestibule to prevent the intrusion of the truck into the facility. Once uncoupled from the trailer, the truck will be moved away from the facility.

Ordinary combustibles. Ordinary combustibles will be present in the Operations Support Area in the form of interior finish material, furniture, clean/dirty clothing, and general supplies. The equivalent ordinary combustible loading is anticipated to be less than $5 \mathrm{lb} / \mathrm{ft}^{2}$ in most areas. The Operations Support Area will be sprinklered.

Fixed ordinary combustibles in the Operating Area will be very sparse. Administrative controls will be provided to keep transient flammable and combustible materials out of the Operating Area.

The MHM gantry crane electrical power is provided via a cable festoon system. A fire involving the jacketing and insulating material on the power cable was insufficient to cause structural damage to the facility. (See Appendix B, 
WHC-SD-SNF-FHA-002, REV. 1

Calculation 2) No hydraulic systems have currently been identified for the MHM.

The MCO Service Station tent was also evaluated and determined to be insufficient to cause significant structural damage. The tent material is a 1 aminated vinyl nylon that meets the NFPA 701, Standard Methods for Fire Tests for Flame-Resistant Textiles and Films, (NFPA 1996), for Test 2, large scale test. (See Appendix B, Calculation 3)

The four electrically powered Tube Vent and Purge Carts would also supply some combustible loading in the form of upholstery and a small ( 1 ton capacity) hydraulic floor crane. This fire loading is less than the crane cable or the tent and was determined to also be insufficient to cause significant damage to the structure.

\subsection{PROTECTION OF ESSENTIAL SAFETY CLASS SYSTEMS}

Structures, systems, and components required to protect the offsite public from excessive radiological or nonradioactive hazardous material exposures are designated Safety Class 1. (The designations have been revised in WHC-CM-4-46, Safety Analysis Manual (WHC-CM-4-46), however, the project has maintained the old designations in accordance with waiver WA-0672.) Structures, systems, and components required to protect the onsite workers from excessive radiological hazardous material exposures are designated Safety Class 2.

For the CSB, basically, all structures and components required to contain the MCOS and confine loose contaminants are classified as Safety Class 1 or 2. The MCO is considered the primary confinement component and the service pit and its hood, the MHM, and storage tubes provide secondary confinement. There are no special fire protection systems that are required for the protection of these safety class systems.

The emergency electrical power system switchgear for both Generator 1 and 2 are designated as Safety Class 2 and are both located in the Electrical Equipment Room. Although the room is provided with sprinklers, a failure of the sprinklers during a fire event in the room could involve both systems and jeopardize the required system redundancy. Separation of the power trains by distance or rated enclosures is warranted. (Finding/Recommendation 7)

Classification of the building filtration system as a Safety Class 2 system requires additional fire protection features as specified by DOE's Filter Plenum standard (DOE 1995a).

\subsection{LIFE SAFETY CONSIDERATIONS}

The design was evaluated against the requirements of NFPA $101^{\circledR}$, Safety to Life from Fire in Buildings and Structures, (Life Safety Code ${ }^{\Theta}$ ), (NFPA 1994C). The 
WHC-SD-SNF-FHA-002, REV. 1

CSB is classified as a storage facility. Although there will be preparation activities at the MCO Service Station prior to staging and periodic monitoring and purging activities, the primary function of the facility is to shelter materia1. Normally accessible areas will encompass the finish grade level of both buildings. Access to the vault area will be required until the completion of construction. Life safety considerations for the vault area during construction are reviewed by Safety to ensure the safe egress of personnel in the event of an emergency. Upon completion of construction, no normal access will be required nor permitted to the vault area of the building.

A satisfactory number of exits from the buildings are provided. Exits are located at the four corners of the Operating Area and an additional exit is provided from the truck vestibule. The Operations Support Area is provided with primary exits at the east and west sides with separate exits for isolated rooms along the north wall. No common path, dead end, or travel distance problems were noted.

All areas of the facility will be provided with normal and emergency lighting. Emergency lighting will be supplied by internal battery packs install on fluorescent fixtures and battery powered wa11 mounted units in areas illuminated by other than fluorescent fixtures. Self-luminous exit and exit directional signs will be positioned as required.

The interior finish meets the specifications required for a storage occupancy.

Employee notification of a fire is accomplished by audible and visual signals initiated by the fire detection and alarm system.

The facility design is in compliance with the Life Safety Code ${ }^{\circledR}$.

\subsection{CRITICAL PROCESS EQUIPMENT}

All of the equipment involved with transferring the MCO from the transport trailer to the storage tube could be considered critical equipment to the extent that they are essential for the transfer operation. The equipment include the receiving gantry crane, the MHM gantry crane, the interface ring, and the portable shield gate. The portable Tube Vent and Purge Carts could also be considered critical for monitoring tube atmosphere and ensuring hydrogen within the tubes is maintained at an acceptable level. Loss of any of these will impact the staging/storage operation. Fire protection of these components from a hydrogen burn event is accomplished by the methods described in Section 4.0. Due to the limited combustible loading in the Operating Area and the acceptable consequences of exposure to a external (non-hydrogen) fire, a building suppression system is not deemed necessary to protect these equipment from fire damage.

\subsection{HIGH VALUE EqUIPMENT}




$$
\text { WHC-SD-SNF-FHA-002, REV. } 1
$$

The criteria for what is considered high value property is subjective. Several individual pieces of equipment have a value approaching or in excess of $\$ 1$ million as reported in the project cost estimates. These items include the Receiving Crane, the MHM Crane, and the facility HEPA filtration system. The cranes are located in the Operating Area where a VESDA air sampling smoke detection system will be provided but no automatic suppression system is planned. Absence of a suppression system is based on the low existing combustible loading of the area and control of transient combustible material into the area. Protection of the HEPA filter room from external fires is provided by the sprinkler system in the Operations Support Area and by the low combustible loading and probability of a fire in the Operating Area that would result in damage to the filter.

\subsection{DAMAGE POTENTIAL}

\subsection{DESCRIPTION}

A Maximum Credible Fire Loss (MCFL) is the property damage that would be expected from a fire, assuming that:

(1) All installed fire protection systems function as designed.

(2) The effect of emergency response is omitted except for post-fire actions such as salvage work, shutting down water systems, and restoring operation.

A Maximum Possible Fire Loss (MPFL) is the value of property, excluding land, within a fire area, unless a fire hazards analysis demonstrates a lesser (or greater) loss potential. This assumes the failure of both automatic fire suppression systems and manual fire fighting efforts. An automatic suppression system is required to be provided in all structures having an MPFL in excess of $\$ 1$ million. When the MPFL exceeds $\$ 50$ million, a redundant fire protection shall be provided that, despite the failure of the primary fire protection system, will limit the loss to $\$ 50$ million.

A Fire Area is a location bounded by construction having a minimum fire resistance rating of two hours with openings protected by appropriately firerated doors, dampers, or penetration seals.

Fire loss is the dollar cost of restoring damaged property to its pre-fire condition. The estimated damage to the facility and contents shall include replacement cost and the cost of decontamination and cleanup.

\section{$10.2 \mathrm{MCFL} / \mathrm{MPFL}$}

The MPFL was determined to be a fire in the Operations Support Area. A simple loss calculation for a hypothetical MHM hydrogen burn and radionuclide release to the Operating Area was performed to determine a rough estimate for comparison to the Operations Support Area fire area event. If this event is 


$$
\text { WHC-SD-SNF-FHA-002, REV. } 1
$$

later proven to not be accurate or bounding, the specific credible hydrogen burn scenario would need to be evaluated to determine whether it would be bounded by the losses for the operations Support Area MCFL and MPFL events.

MCFL. The MCFL is considered to be a fire in the Control Room. The Digital Collection System (DCS) and Health Protection System (HPS) software and some of the system hardware are located in the Control Room. The software for the systems is valued at approximately $\$ 500,000$ and the hardware is valued at approximately $\$ 120,000$. Even if the installed sprinkler system functioned as designed, very little would be considered salvageable due to the sensitivity of the equipment to heat and smoke. Installation and testing of the replacement equipment is estimated at $\$ 70,000$ which is $50 \%$ of the initial facility wide installation cost. Repair/reconstruction of the room is estimated at $\$ 100 / \mathrm{ft}^{2}$ for a total of approximately $\$ 35,000$. Cleanup efforts would not entail any unusual hazards or methods and is considered to be included in the reconstruction of the room. The MCFL could reach $\$ 725,000$.

MPFL. The MPFL is considered to be a fire in the Operations Support Area fire area. The two generator rooms were not included in the fire area due to the two-hour fire rated walls separating these rooms from the rest of the Operations Support Area. The Operating Area fire area was evaluated but losses from a fire event were determined to be bounded by the Operations Support Area fire due to the limited and dispersed combustible loading within the Operating Area.

For simplicity, damage to a 17 equipment and structures within the Operation Support Area fire area was assumed. The cost of equipment, construction, engineering, and project management for replacement of the damaged facility were based on project estimates.

Procurement estimates were $\$ 5.18 \mathrm{million}$ for the Personnel/Utility/Support Area. This figure is considered conservative since it includes some equipment located outside the Operations Support Area. An additional $\$ 1.4$ million for the HEPA filter system, not included in the project estimates, al so needs to be included. Equipment losses would equal approximately $\$ 6.58$ million.

Construction includes the installation of the systems as well as the construction of the structure. Cleanup of the damaged facility is included in this cost. The estimated cost was $\$ 2.85 \mathrm{milli}$ ion and is also considered conservative since some work external to the building is included and some work, such as the foundation, could be salvaged.

Engineering, construction management, and project management were estimated at $10 \%$ of the initial project estimates resulting in a total of $\$ 2.35 \mathrm{million}$.

The total cost to replace the equipment and structure is $\$ 11.78$ million. This does not include any environmental cleanup of the radionuclides dispersed from the building HEPA filtration system which is also included in the fire area. The inventory of radionuclides was not determined, however, due to the venting of the MCOs through local HEPA filters prior to exhausting through the 
WHC-SD-SNF-FHA-002, REV. 1

building filter, the radionuclides content is anticipated to be relatively low. Environmental cleanup costs are not likely to challenge the approximately $\$ 38$ million margin between the $\$ 50$ million MPFL 1 imit and the approximately $\$ 12$ million equipment structure replacement cost. The cost to cleanup ground contamination is estimated at $\$ 5.50 / \mathrm{ft}^{2}$ (WHC 1993). This MPFL is acceptable based on the installation of a sprinkler system in the Operations Support Area.

Although no specific hydrogen burn event was evaluated, a release of radionuclides from a confinement component into the Operating Area as a result of a hydrogen burn and overpressurization was evaluated to determine general loss estimates. An event damaging the MHM and releasing radionuclides was hypothesized. The cost factors are again the cost to repair/replace equipment, the cost of engineering/management, and the cleanup cost. Using project estimates without accounting for any salvage, the replacement and construction cost for the MHM is approximately $\$ 2.2$ million. Engineering and management is estimated at $\$ 100 / \mathrm{hr}$ for 2,000 man-hours for a total of $\$ 0.2$ million. The event assumes no loss of building confinement integrity therefore cleanup is limited to the Operating Area. An area of about 108,000 $\mathrm{ft}^{2}$ (total inside surface plus equipment) was assumed to require decontamination at a cost of approximately $\$ 15 / \mathrm{ft}^{2}$ for a total of $\$ 1.6$ million. The $\$ 15 / \mathrm{ft}^{2}$ estimate was used in Appendix $K$ of the FHA for the FFTF (WHC 1994) for cleanup of radioactive sodium aerosol. The MPFL for this event is $\$ 4.0$ million which is bounded by the Operations Support Area MPFL. The $\$ 4.0$ million loss, however, exceeds the $\$ 1.0 \mathrm{million}$ limit for providing an automatic suppression system. Therefore, an exemption from this requirement would also be needed in addition to the 5,000 square feet criteria.

Release of radioactive material to the environment in quantities requiring cleanup were assumed not to occur. Any release from the building would need to pass through the building ventilation filtration system and be exhausted through the stack resulting in wide dispersion. However, if concentrations above cleanup criteria were measured, ground contamination cleanup would be required at an estimated cost of $\$ 5.50 / \mathrm{ft}^{2}$ rate. An additional ground contamination cleanup cost that would increase the $\$ 4.0$ million MHM loss scenario above the $\$ 11.78$ million Operations Support Area loss scenario is not envisioned.

\subsection{FIRE DEPARTMENT RESPONSE}

The standard response to an alarm condition in the 200 East Area will be by the Hanford Fire Department (HFD) from the 200 Area Fire Station. Response time to the CSB will be approximately 5 minutes. When manned, a crew from the 100 Area Fire Station will be dispatched simultaneously with an estimated response time of 10 minutes. Vehicle access to the facility will be provided by a paved access road that is included as part of the facility construction.

The HFD is fully staffed, trained, and equipped. No Fire Brigade is planned for this facility. 


$$
\text { WHC-SD-SNF-FHA-002, REV. } 1
$$

A Pre-Fire Plan provides valuable information about a structure and its contents to assist the fire department in their response to a fire. A PreFire Plan for the CSB should be prepared by the HFD prior to operation of the facility. The plan should address any constraints on the use of water within the Operating Area.

\subsection{RECOVERY POTENTIAL}

The anticipated recovery from the MCFL would involve repair of the Control Room and repair/replacement of equipment. Recovery from damage to the DCS and HPS is dependent on procurement, installation, and testing of replacement equipment. Four to six months are estimated for the return of the equipment to functional status. Experience among major computer equipment users and manufacturers has shown that certain recovery methods performed promptly can increase the saivageability of the equipment. Manufacturers can provide guidance on these recovery methods.

The recovery from the MPFL (loss of the Operations Support Area excluding the generators) would involve cleanup and repair/replacement of the damaged structure and equipment. Once funding for the restoration is approved, an estimated 18 months would be required for procurement of equipment and materials and construction.

The impact on the program is largely dependent on whether SNF is still being transferred, or staged, or in storage. It is assumed that temporary or alternate systems can be established to replace the loss of the Operations Support Area much sooner than the 18 months estimated in the previous paragraph. Nevertheless, probable schedule impacts, if transfers have not been completed, and additional operational impacts will be incurred. The impact of any design basis accident will be minimized if the Safety $\mathrm{Cl}$ ass components and systems are protected such that operations can continue. The emergency electrical power system and building ventilation filtration system are two systems required for continued operation of the facility during recovery from the MPFL.

\subsection{POTENTIAL FOR A TOXICOLOGICAL, BIOLOGICAL, AND/OR RADIOLOGICAL INCIDENT DUE TO A FIRE}

No toxicological or biological consequences resulting from any credible fire is anticipated.

Radiological incidents resulting in onsite exposure above the risk guidelines given in WHC-CM-4-46 were analyzed in WHC-SD-SNF-RPT-004. One scenario invoTves a hydrogen burn within the MHM. The MHM is assumed to survive the increased pressure of the burn. However, the pressurized gas and contaminants are released to the CSB when the MHM is opened to lower the MCO into a CSB storage tube. The offsite consequences of the analyzed events were shown to be within the WHC-CM-4-46 risk guidelines. 


$$
\text { WHC-SD-SNF-FHA-002, REV. } 1
$$

In the MPFL scenario, involvement of the building HEPA filter was assumed. However, no offsite radiological incident due to a hydrogen burn event was expected due to the small radionuclide inventory anticipated and the wide dispersion from the fire plume. Under credible conditions with the sprinkler system functional, the Filter Room is deemed to be adequately protected from the MPFL fire.

\subsection{EMERGENCY PLANNING}

The CSB shall be designed with the goal to eliminate the need for off-site evacuation and sheltering. Prior to operation of the facility, a Building Emergency $P 1$ an will be required to address potential emergency conditions

(including fire) and the proper responses to minimize dangerous conditions and damage.

\subsection{SECURITY AND SAFEGUARDS CONSIDERATIONS RELATED TO FIRE PROTECTION}

Access to the CSB site and the CSB will be controlled. HFD access in response to an alarm will need to be coordinated and documented so as not to impact or otherwise adversely affect fire protection efforts.

\subsection{NATURAL HAZARDS IMPACT ON FIRE SAFETY}

The natural phenomena hazards design requirements are discussed in WHC-SD-SNF-DB-009 (Ta71man 1996). Structures and equipment designed as Safety Class 1 reflect their ability to withstand all design-basis natural phenomena hazards. No significant impact to fire safety is expected as a result of natural phenomena hazards.

\subsection{EXPOSURE FIRE POTENTIAL}

The CSB site plan was reviewed in accordance with NFPA 80A, Recommended Practice for Protection of Buildings from Exterior Fire Exposures (NFPA 1993), for exposure hazards. NFPA $80 \mathrm{~A}$ is intended to combat the ignition of combustibles, by means of radiative heat, in or on exposed buildings. A minimum clear separation of distance of 60 feet on all sides of the CSB is specified by the design to meet a UBC requirement. Separation distance is calculated per NFPA $80 \mathrm{~A}$ by multiplying a guide number (determined from Table 2-3 based on width vd height or height vd width ratios) by the lesser dimension then adding 5 feet. NFPA $80 \mathrm{~A}$ allows certain exceptions and reductions of separation distances.

Part of the evaluation for proposed sites for structures in the vicinity of the CSB will be to calculate the required separation distance between structures per NFPA $80 A$. Separation distances based on the CSB as the exposing structure are approximately $125 \mathrm{ft}$ to the south and $140 \mathrm{ft}$ to the 


$$
\text { WHC-SD-SNF-FHA-002, REV. } 1
$$

east and west. These distances assume a light severity and a conservative $100 \%$ opening. No structures are presently planned to be located on these sides of the CSB.

Structure M0-046 wi1l be located about $17 \mathrm{ft}$ from the north side of the CSB. No exposure hazard is considered to exist because both M0-046 and the north part of the CSB (the Operations Support Area) are fully sprinklered.

Two 500 gallon fuel oil tanks will be located approximately 8 ft from the CSB to the south and from MO-046 to the east. The minimum separation distance between the tanks and the nearest important building as specified by the Uniform Fire Code (UFC 1994) and NFPA 30 is $5 \mathrm{ft}$.

A 750 kVA pad mounted transformer will be located east of the Electrical Equipment room. A dike filled with crushed rock will enclose the transformer installation to contain any spilled insulating oil. Separation between the CSB and the diked area surrounding the transformer will be approximately $35 \mathrm{ft}$. This distance is adequate to not present an exposure hazard.

Range fire presents an exposure potential to the CSB. A clear space of at least $60 \mathrm{ft}$ will be provided on all sides of the CSB. Unpaved areas will be overlaid with crushed rock surface.

No exposure hazards presently exist to or from the CSB. 
WHC-SD-SNF-FHA-002, REV. I

\subsection{RECOMMENDATIONS}

1. The facility was designated a UBC occupancy classification of F-2. A classification of $\mathrm{H}-7$ is more appropriate for the Operating Area due to the radiological hazards that could be released into that space. The additional fire protection features that would be required by an $\mathrm{H}-7$ classification would add little benefit towards the fire or radiological safety of the facility. Evaluate the classification designation and any design changes, waivers, etc. that may result from a reclassification.

(Section 3.0)

2. The hydrogen studies are not yet complete. The basis for the Safety class designation of equipment is in part based on the probability of a release, possibly as a result of a hydrogen burn event, and the consequences of the event. Complete the hydrogen studies to verify presently designated Safety $\mathrm{Class}$ systems and components are adequate. (Section 4.0)

3. The building filtration system is designated as a Safety Class 2 system. DOE-RL 5480.7 requires special protection for final HEPA filters in a nuclear facility. These special protection features include separation by fire rated walls, detection, and suppression. The CSB Filter Room is not designated as a rated enclosure and dedicated detection and suppression systems are not in the current design. Comply with the Filter Plenum Fire Protection standard. If the requirements of the Filter Plenum Fire Protection standard are not to be applied, an equivalency or deviation must be requested from DOE-RL Occupational Safety Programs Branch. (Section 4.0)

4. One of the bases for not requiring sprinklers above the Operating Deck is the minimization of combustible loading. Combustibles on fixed equipment are sufficiently low that damage to the equipment or the structure is within acceptable limits even without suppression intervention. To maintain this condition, administrative controls are required to keep transient flammable and combustible materials out of the Operating Area. (Section 4:0)

5. DOE 5480.7A requires that an automatic suppression system be provided for new structures over 5,000 square feet and in all structures having an MPFL exceeding \$l million. If a sprinkler system will not be provided, an exemption from this requirement is needed. The exemption would be based on the absence of significant existing combustible loading, the control of transient combustible loading, the minimal benefit of a sprinkler system, and the reduced potential for moisture entering the storage tube and possibly increasing hydrogen generation. (Section 4.0, 10.2)

6. DOE 6430.1A, Section 1530-99.0, requires a minimum of two reliable, independent sources of water. Presently, only one source feeds the existing loop. Another source is required. Tie-in of existing fire 


\section{WHC-SD-SNF-FHA-002, REV. I}

pumps and a water storage tank located north of the CSB is an option to meet this requirement. (Section 4.0)

7. The emergency electrical system is designated as Safety $\mathrm{Class} 2$. The generators are separated, however, the switchgear for both electrical power trains are located adjacent to each other in the Electrical Room. A single fire event can cause failure of both trains and jeopardize the required system redundancy. Separation by remoteness or rated enclosure is required. (Section 6.0) 
WHC-SD-SNF-FHA-002, REV. 1

\subsection{REFERENCES}

DOE, 1989, Genera7 Design Criteria, DOE Order 6430.1A, U.S. Department of Energy, Washington, D.C.

DOE, 1993, Fire Protection, DOE Order 5480.7A, U.S. Department of Energy, Washington, D.C.

DOE, 1995, Filter Plenum Fire Protection, DOE STD-XXXX-95, Proposed, U.S. Department of Energy, Washington, D.C.

DOE-RL, 1994, Fire Protection, RLID 5480.7, U.S. Department of Energy, Richland Operations office, Richland, Washington.

NFPA 1993a, National Fire A7arm Code, NFPA 72, National Fire Protection Association, Quincy, Massachusetts.

NFPA 1993b, Recommended Practice for Protection of Buildings from Exterior Fire Exposures, NFPA 80A, National Fire Protection Association, Quincy, Massachusetts.

NFPA 1993c, Flammable and Combustible Liquids Code, NFPA 30, National Fire Protection Association, Quincy, Massachusetts.

NFPA 1994a, Standard for the Installation of Sprinkler Systems, NFPA 13, National Fire Protection Association, Quincy, Massachusetts.

NFPA 1994b, Standard for Portable Fire Extinguishers, NFPA 10, National Fire Protection Association, Quincy, Massachusetts.

NFPA 1994c, Code for Safety to Life from Fire in Buildings and Structures, NFPA 101, National Fire Protection Association, Quincy, Massachusetts.

Tallman, A. M., 1996, Canister Storage Building Natural Phenomena Hazards, WHC-SD-SNF-DB-009, Rev. 1, Westinghouse Hanford Company, Richland, Washington.

UFC, 1994, Uniform Fire Code, International Fire Code Institute, Austin, Texas.

WHC, 1993, Interim Stabilization of Radioactive Surface Contamination Associated with UN-216-E-44, WHC-SD-DD-TI-078, Rev. 0, Westinghouse Hanford Company, Richland, Washington.

WHC, 1994, Fire Hazards Analysis for the Fast Flux Test Facility, WHC-SD-FFFHA-001, Appendix $\mathrm{K}$, Westinghouse Hanford Company, Richland, Washington.

WHC, 1996a, Phase l Fire Hazard Analysis for the Canister Storage Building Storage Vault, WHC-SD-SNF-FHA-002, Rev. 0, Westinghouse Hanford Company, Richland, Washington. 
WHC-SD-SNF-FHA-002, REV. 1

WHC, 1996b, Spent Nuclear Fuel Project, Canister Storage Building Safety Analysis Report Phase 2, Safety Analysis Document Supporting Canister Storage Building Subsurface and Operating Deck Construction, WHC-SD-SNFRPT-004, Rev. 2, Westinghouse Hanford Company, Richland, Washington.

WHC, 1996c, CSB Performance Specification, WHC-S-0425, Rev. 1, Westinghouse Hanford Company, Richland, Washington.

WHC-CM-4-41, Fire Protection Program Manual, Westinghouse Hanford Company, Richland, Washington.

WHC-CM-4-46, Safety Analysis Manual, Westinghouse Hanford Company, Richland, Washington. 
WHC-SD-SNF-FHA-002, REV 1

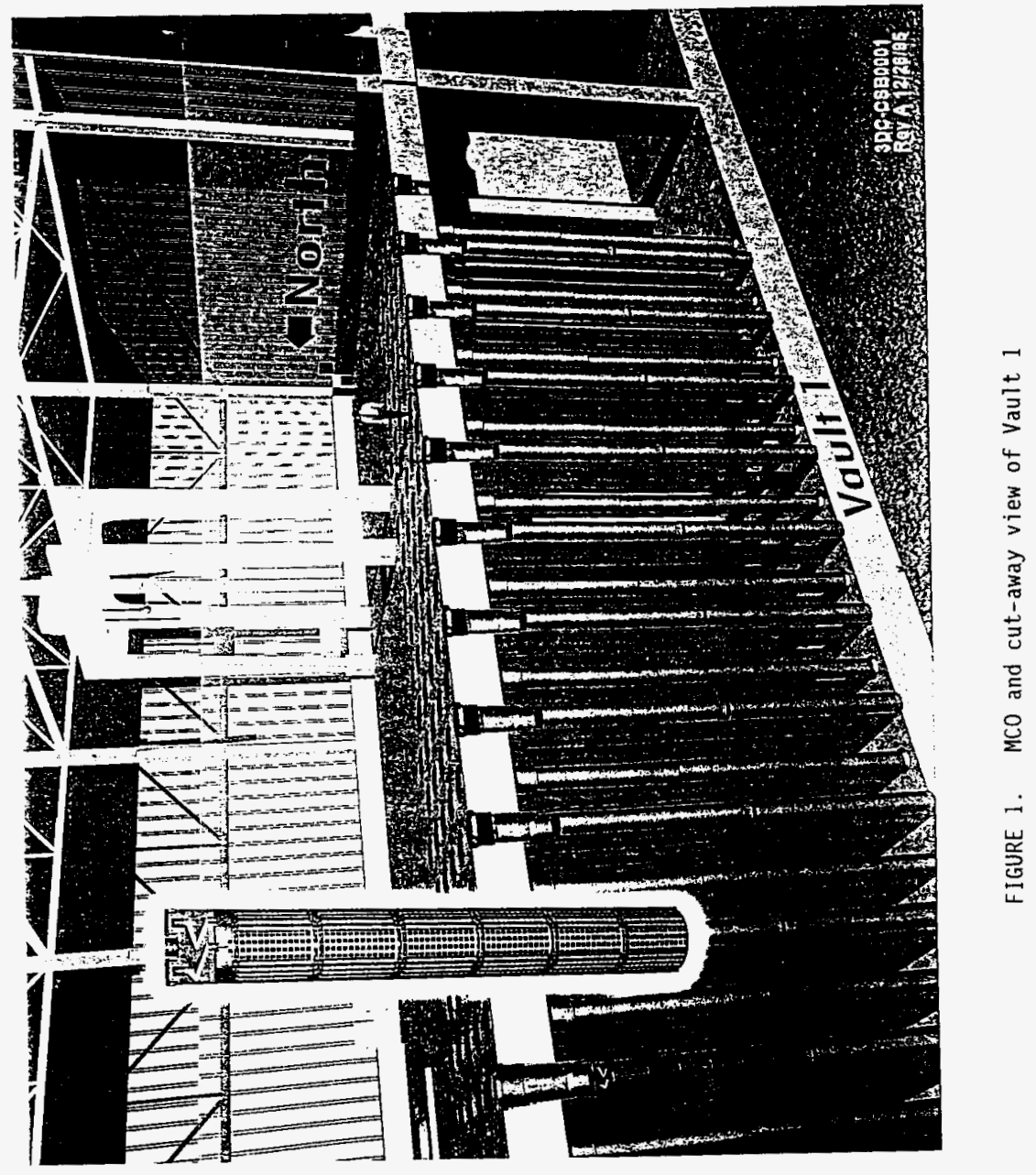


WHC-SD-SNF-FHA-002, REV 1

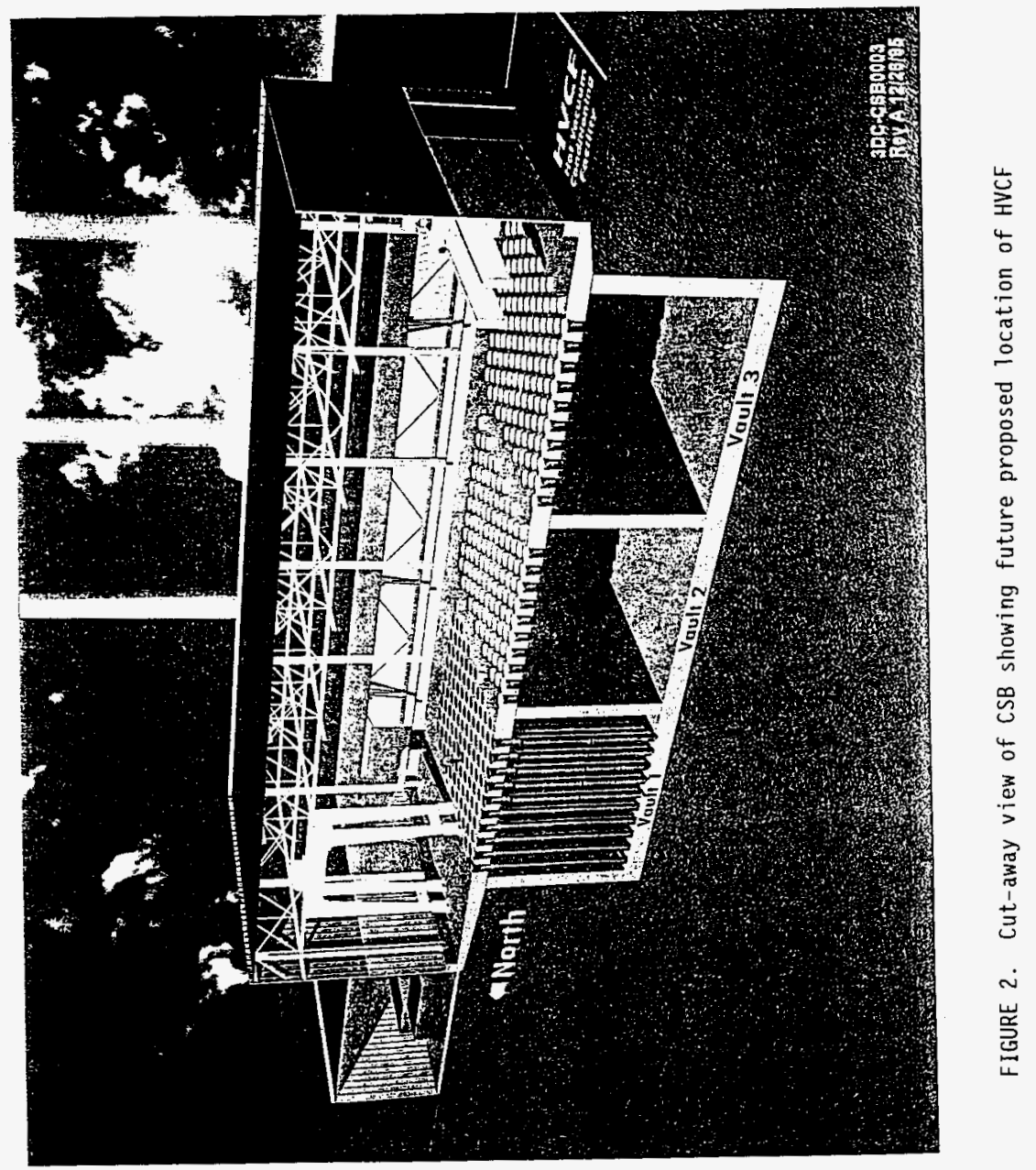


WHC-SD-SNF-FHA-002, REV 1

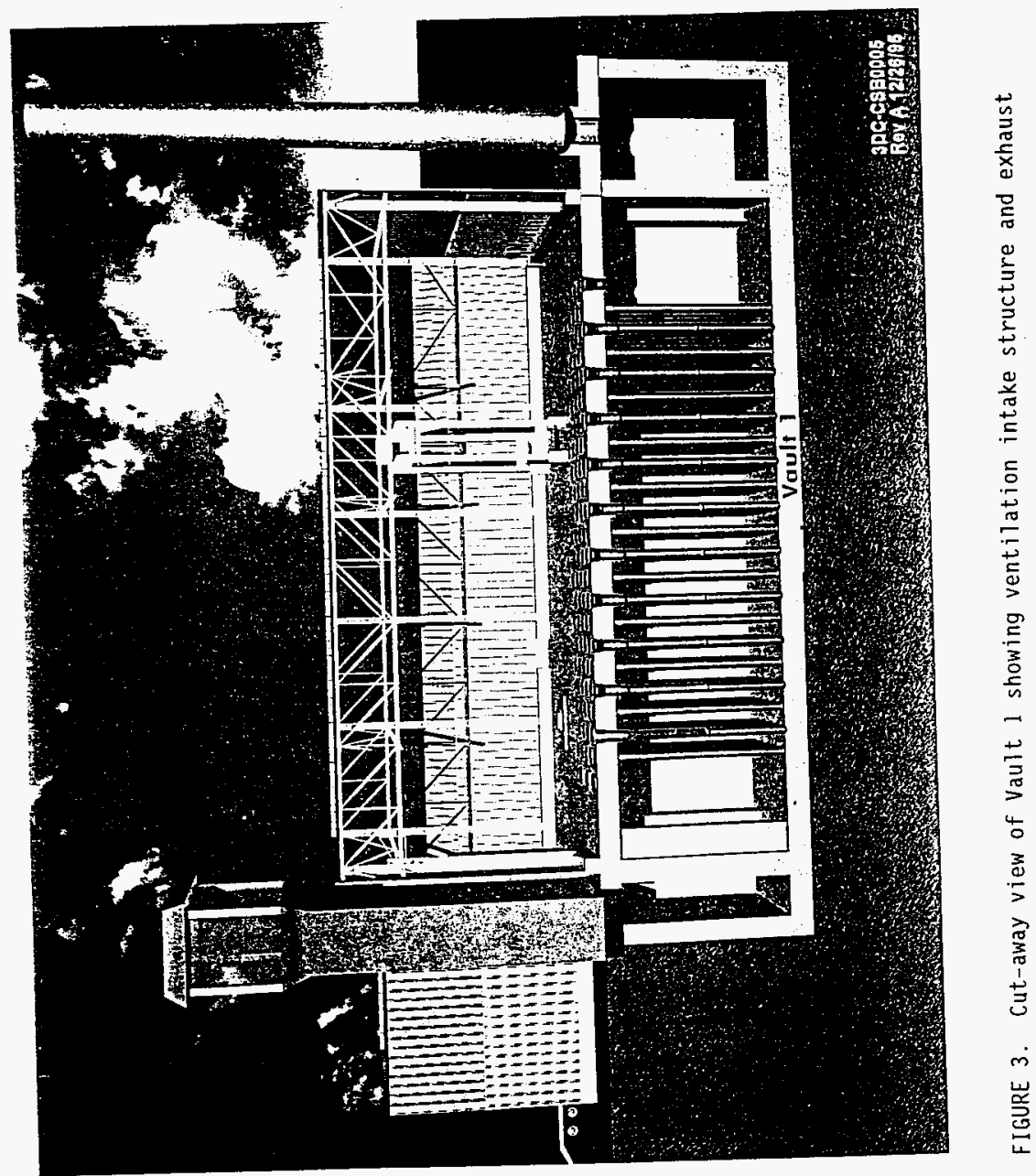


WHC-SD-SNF-FHA-002, REV 1

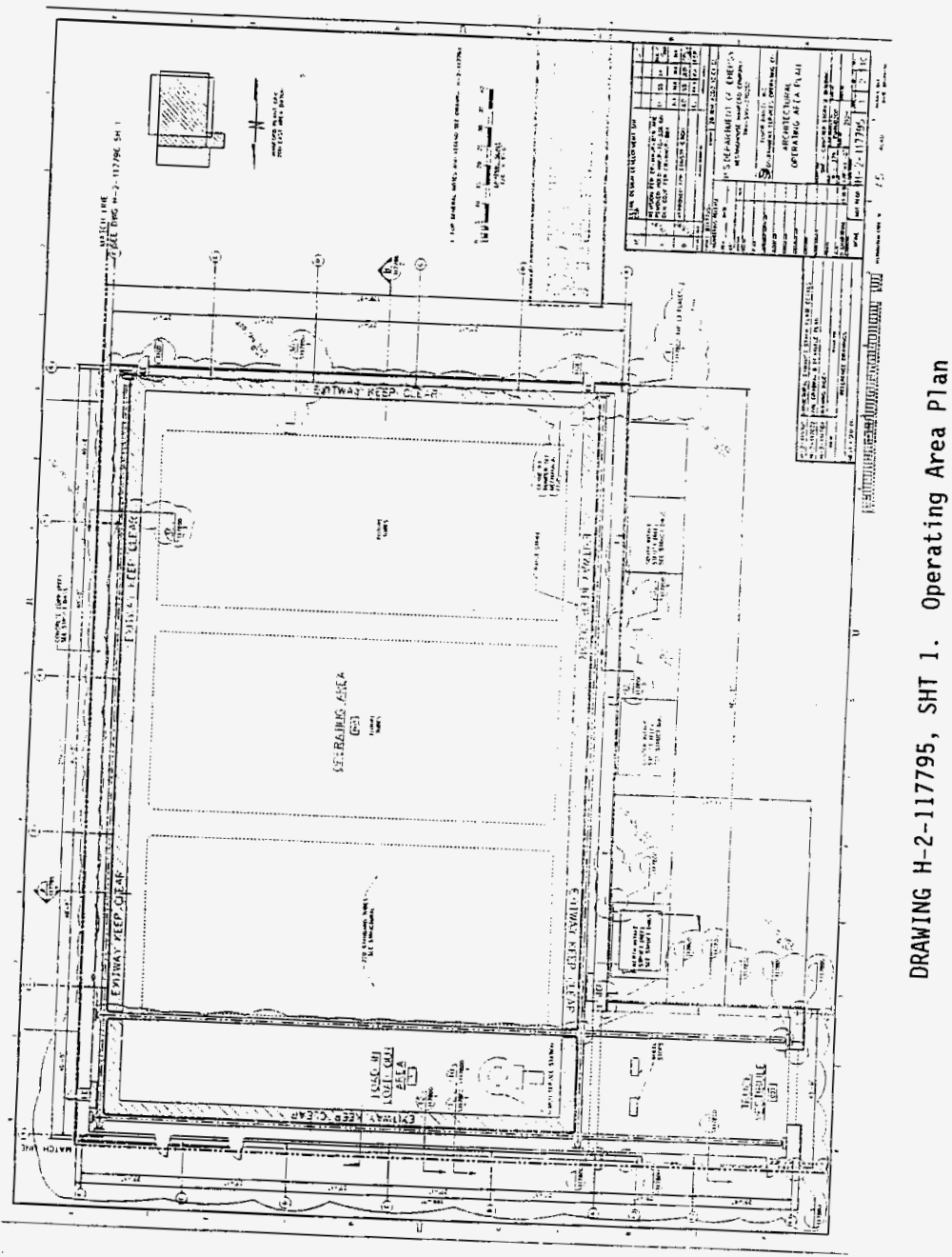


WHC-SD-SNF-FHA-002, REV I

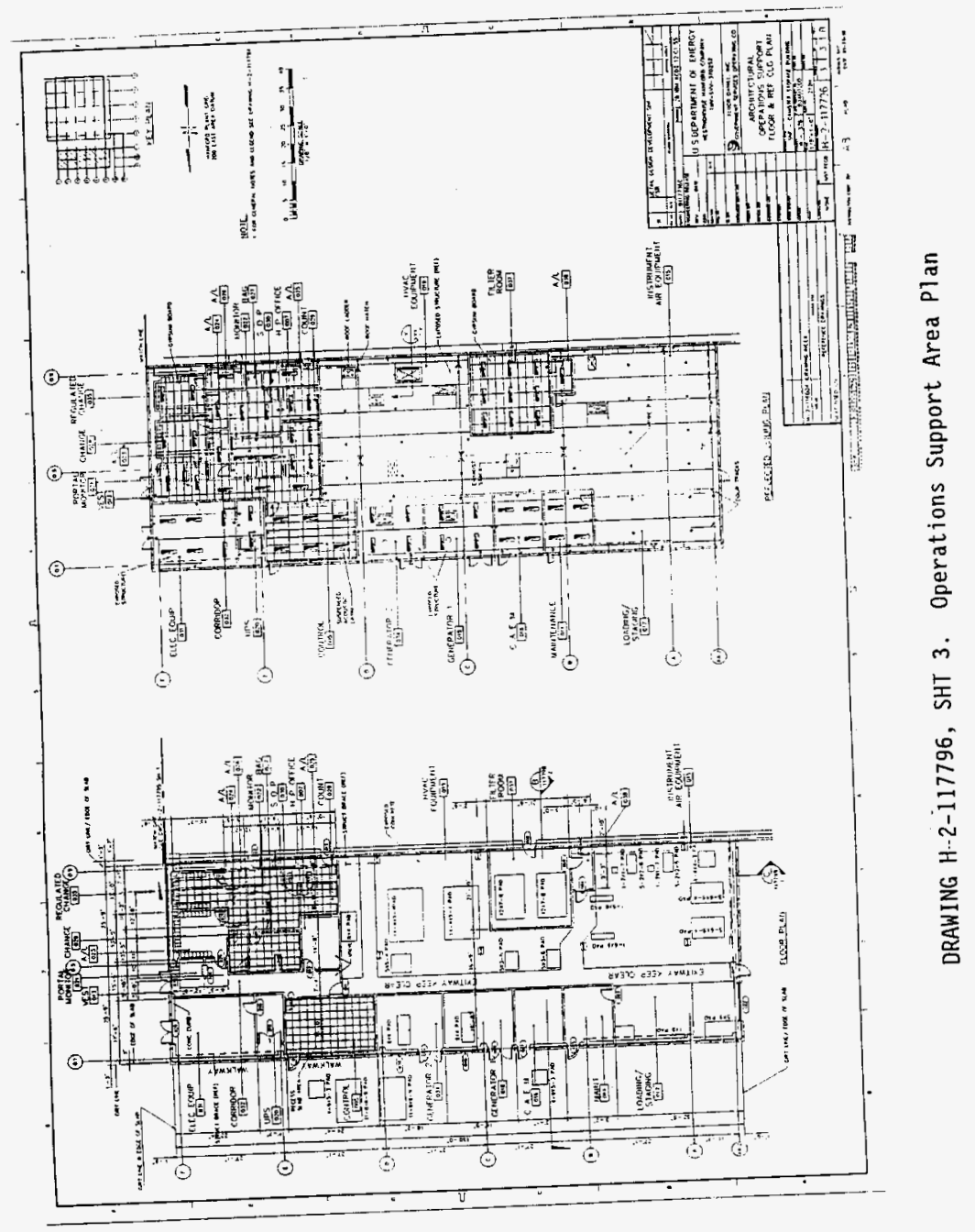


WHC-SD-SNF-FHA-002, REV. 1

THIS PAGE LEFT BLANK 
WHC-SD-SNF-FHA-002, REV. 1

APPENDIX A

DESCRIPTION OF STAGING/STORAGE PROCESS 
WHC-SD-SNF-FHA-002, REV. I

THIS PAGE LEFT BLANK 


\section{WHC-SD-SNF-FHA-002, REV. 1 \\ DESCRIPTION OF STAGING/STORAGE PROCESS}

The CSB consists of three equally sized below-grade concrete vaults covered by a concrete operating deck. Each vault has air plenums on opposite sides to provide natural convective cooling. One of the three vaults will be used to store the MCOS and will contain 220 vertical carbon steel storage tubes. The other two vaults will remain available for future use. Each storage tube will accommodate two MCOs, stacked two-high, and will be closed and sealed by means of a shielded plug installed at the operating deck. The operating deck and other operations areas such as the load-in/load-out area and the service pit will be covered by a steel building. Support functions (e.g., the control room, change room, and maintenance areas) and equipment (e.g., heating ventilation, and air conditioning and electrical power equipment and controls) will be housed in an interconnecting building adjacent to the operations structure.

When it arrives at the CSB, each MCO will contain a maximum of 270 MKIV fue 1 elements or 288 MKIA fuel elements. The MCO, still in a shipping cask in a vertical position, will be brought by a transport trailer to the load-in/loadout area within the CSB structure. The shipping cask will be removed from the transport trailer by crane and lowered into the cask service pit. A portable hood will then be placed over the pit and the cask lid removed so the MCO can be purged with inert gas. The MCO will then be moved by the MHM to a shortterm staging location within one of the vault tubes where it will await conditioning. The MHM is a bridge crane that can travel the entire length of the operating platform. It is capable of holding individual MCOs within a confined bell structure with a sliding gate on its bottom to provide confinement for the MCO during transport. The MCO will be maintained in temporary staging with an inert cover gas. It is expected that during initial staging at the CSB, venting of hydrogen from the MCOs will be required because of a small amount of remaining free water and the existence of chemically bound water.

The location of the conditioning facility will be collocated with the CSB. When the conditioning facility is ready to receive the MCOs, the MHM will retrieve the $M C O$ and transport it to the conditioning facility, where a temperature of about $300^{\circ} \mathrm{C}$ and a pressure of about 3 torr will remove the remaining free water and most of the chemically bound water. This drying will be followed by intraduction of oxygen into the $\mathrm{MCO}$ at about $150^{\circ} \mathrm{C}$ to stabilized small metal particles and porous surfaces.

After conditioning is accomplished, an inert cover gas will be placed in the MCOs, which will then be sealed and returned to the CSB for dry interim storage until a suitable long-term repository can be established. With conditioning accomplished, it is expected that no venting will be required during interim dry storage at the CSB. 
WHC-SD-SNF-FHA-002, REV. 1

THIS PAGE LEFT BLANK 
WHC-SD-SNF-FHA-002, REV. 1

APPENDIX B

\section{CALCULATIONS}


WHC-SD-SNF-FHA-002, REV. 1

THIS PAGE LEFT BLANK 
WHC-SD-SNF-FHA-002, REV. I

\section{CALCULATIONS}

CALCULATION 1, GENERATOR ROOM FIRE. This evaluation was performed to determine the adequacy of the 2-hour rating for the Generator Room 018 or 034 from a diesel fuel oil fire.

100 gals (maximum)

$7.5 \mathrm{lb} / \mathrm{gal}$ (based on specific gravity of 0.9 for diesel fuel oil No. 2) 19,440 Btu/1b (diesel fuel oil No. 2, from Micromedex, Chemical Hazard Response Information System)

$288 \mathrm{ft}^{2}$ (Conservative room area)

$100 \mathrm{gal} \times 7.5 \mathrm{lb} / \mathrm{gal} \times 19,440 \mathrm{Btu} / \mathrm{lb} \div 288 \mathrm{ft}^{2}=50,625 \mathrm{Btu} / \mathrm{ft}^{2}$

The following evaluation was based on tables and figures from the FIRE PROTECTION HANDBOOK, Seventeenth Edition, Section 6\Chapter 6, "Confinement of Fire in Buildings". This method used the standard time-temperature curve to arrive at a representative fire duration.

The $50,625 \mathrm{Btu} / \mathrm{ft}^{2}$ fire load was converted to a value of pounds $/ \mathrm{ft}^{2}$ of ordinary combustibles which is used by Fig. 6-6B.

$$
50,625 \mathrm{Btu} / \mathrm{ft}^{2} \div 8,000 \mathrm{Btu} / 1 \mathrm{~b} \text { ordinary combustibles }=6.33 \mathrm{lb} / \mathrm{ft}^{2}
$$

Temperature Curve $\mathrm{E}$ (Standard Fire Exposure-Severe) was chosen for use. Flammable liquids occupancy is one type of occupancy to which the curve is applicable. A load of $6.33 \mathrm{lb} / \mathrm{ft}^{2}$ on Line $E$ of $\mathrm{Fig}$. 6-6B equated to a time of approximately 38 minutes.

A fuel oil fire scenario was also run on the Law's Severity Correlation routine of FPETOOL as a second check of the above calculation. One panel of the double doors was assumed to be open to provide ventilation for the fire. With this input a fire of 48 minutes equivalent fire severity will develop. A two hour fire rated wall is adequate to account for other combustibles in the rooms and confine the fuel oil fire within the generator room. 


$$
\text { WHC-SD-SNF-FHA-002, REV } 1
$$

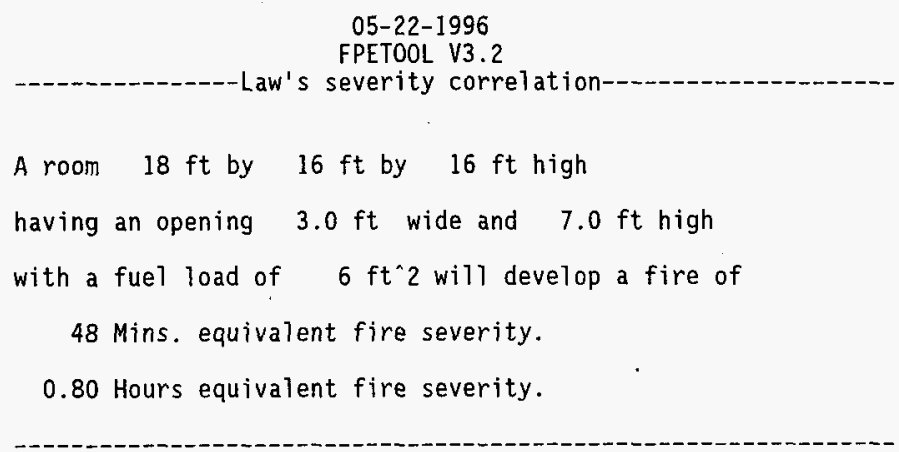

FPETOOL Routine - Generator Room 
WHC-SD-SNF-FHA-002, REV. 1

CALCULATION 2, CRANE CABLE FIRE. The MHM crane is valued at a little over $\$ 2$ million, however, replacement of damaged cable and cleanup from a cable fire is estimated at less than $\$ 200,000$. Fifty-thousand do 11 ars $(\$ 50,000)$ was estimated for cable and the festoon system material replacement. Four-hundred hours at a conservative $\$ 100 /$ hour of labor was estimated for removal/installation (150 hours), hookup/testing ( 100 hours), and debris and smoke cleanup (150 hours) for a total labor cost of $\$ 40,000$. A $100 \%$ contingency factor was applied for an estimate of $\$ 180,000$.

This calculation was performed to determine is additional losses from damage to the structure could be anticipated as a result of this fire.

The festooned cable is assumed to be stored in its most concentrated condition $(6.1 \mathrm{~m}$ by $.3 \mathrm{~m}$ ) in a corner of the building $4.9 \mathrm{~m}$ below the ceiling.

$62.5 \mathrm{~m}$ by $41.2 \mathrm{~m}$ by $16.7 \mathrm{~m}$ high Operating Area

$61 \mathrm{~m}$ of cable

$0.0026 \mathrm{~m}^{2}\left(4 \mathrm{in}^{2}\right)$ cross-sectional insulating material area assumed

$20 \mathrm{~kJ} / \mathrm{g}$ potential heat value (estimated for a combination of neoprene jacketing and PE/PCV conductor insulation from EPRI NP-1200 Categorization of Cable Flammability)

$1,208 \mathrm{~kg} / \mathrm{m}^{3}$ density of jacketing and insulation

$375 \mathrm{~kW} / \mathrm{m}^{2}$ heat release rate (estimated for neoprene and PE/PVC material from EPRI NP-1200)

$9.25 \mathrm{~m}^{2}$ total burn area

$375 \mathrm{~kW} / \mathrm{m}^{2} \times 9.25 \mathrm{~m}^{2}=3,469 \mathrm{~kW}(\mathrm{~kJ} / \mathrm{s})$ maximum burn rate

$1,208 \mathrm{~kg} / \mathrm{m}^{3} \times .0026 \mathrm{~m}^{2} \times 61 \mathrm{~m} \times 20,000 \mathrm{~kJ} / \mathrm{kg} \div 3469 \mathrm{~kJ} / \mathrm{s}=1,105$ seconds burn duration

The data was inputted to the FASTLite fire model program to determine if the critical upper layer temperature would approach the critical temperature for structural steel. The critical temperature is described as the temperature at which collapse is impending and approximated at $811^{\circ} \mathrm{K}\left(1000^{\circ} \mathrm{F}\right)$. The yield strength and modulus of elasticity of steel at these temperatures decreased to about $60 \%$ of the value at normal room temperature. The American Institute for Steel Construction Specification for the Design, Fabrication and Erection of Structural steel Buildings limits the maximum permissible design stress to approximately $60 \%$ of the yield strength. The program showed that the upper layer temperature would remain below $400^{\circ} \mathrm{K}\left(260^{\circ} \mathrm{F}\right)$.

The plume temperature was also calculated to determine if the roofing material, which includes a sandwiched polystyrene material, would become involved. The ignition temperature of polystyrene is listed at $846^{\circ} \mathrm{K}$ per Table A- 6 of the Fire Protection Handbook, Seventeenth Edition. The FASTLite Ceiling Plume Temperature calculation estimated a temperature of $430^{\circ} \mathrm{K}$ $\left(315^{\circ} \mathrm{F}\right)$.

No damage to the structure is predicted. 
CFAST Version 2.2.1 User Defined Base Case

Data file is TMPRN3 (Checksum 00000000)

OVERVIEW

Compartments Doors, ... Ceil. Vents, ... MV Connects

MHM CABLE BURN

$\begin{array}{llll}1 & 1 & 0 & 0\end{array}$

Simulation Print History Restart

Time Interval Interval Interval

(s) (s) (s) (s)

$\begin{array}{llll}1125 & 120 & 20 & 0\end{array}$

Ceiling jet is on for all

COMPARTMENTS

Compartment Width Depth Height Ceiling Floor

\begin{tabular}{cccccc} 
& $(\mathrm{m})$ & $(\mathrm{m})$ & $(\mathrm{m})$ & $\begin{array}{l}\text { Height } \\
(\mathrm{m})\end{array}$ & $\begin{array}{l}\text { Height } \\
(\mathrm{m})\end{array}$ \\
\hline 1 & 62.48 & 41.15 & 16.76 & 16.76 & 0.00
\end{tabular}

VENT CONNECTIONS

Horizontal Natural Flow Connections (Doors, Windows, ...)

\begin{tabular}{lllccc}
$\begin{array}{l}\text { From } \\
\text { Compartment }\end{array}$ & $\begin{array}{l}\text { To } \\
\text { Compartment }\end{array}$ & $\begin{array}{l}\text { Vent } \\
\text { Number } \\
(\mathrm{m})\end{array}$ & $\begin{array}{l}\text { Width } \\
(\mathrm{m})\end{array}$ & $\begin{array}{l}\text { Sill } \\
\text { Height } \\
(\mathrm{m})\end{array}$ & $\begin{array}{l}\text { Soffit } \\
\text { Height } \\
(\mathrm{m})\end{array}$ \\
\hline 1 & Outside & I & 0.91 & 0.00 & 2.13
\end{tabular}

There are no vertical natural flow connections

THERMAL PROPERTIES

Compartment Ceiling Wall Floor

1 STEELSHT STEELSHT CONCRETE

Thermal data base used: THERMAL.DF

$\begin{array}{lccclc}\text { Name } & \text { Conductivity } & \text { Specific heat } & \text { Density } & \text { Thickness } & \text { Emissivity } \\ \text { STEELSHT } & 48.0 & 559 & 7.854 E+03 & 1.500 \mathrm{E}-03 & 0.900 \\ \text { CONCRETE } & 1.75 & 1.000 \mathrm{E}+03 & 2.200 \mathrm{E}+03 & 0.150 & 0.940\end{array}$

FIRES 


\section{Compartment :}

Fire Type:

Position $(x, y, z): \quad 1.221 .52$

Relative Humidity: 50.0

Lower 02 Limit: $\quad 10.00$

Pyrolysis Temp.: $\quad 311$.
1

Unconstrained

8.23

\begin{tabular}{rllll}
$\begin{array}{l}\text { Time } \\
(\mathrm{s})\end{array}$ & $\begin{array}{l}\text { Fmass } \\
(\mathrm{kg} / \mathrm{s})\end{array}$ & $\begin{array}{l}\text { Hcomb } \\
(\mathrm{J} / \mathrm{kg})\end{array}$ & $\begin{array}{l}\text { Fqdot } \\
(\mathrm{W})\end{array}$ & $(\mathrm{m})$ \\
\hline 0. & $0.00 \mathrm{E}+00$ & $2.00 \mathrm{E}+07$ & $0.00 \mathrm{E}+00$ & $0.00 \mathrm{E}+00$ \\
10. & 0.17 & $2.00 \mathrm{E}+07$ & $3.47 \mathrm{E}+06$ & $0.00 \mathrm{E}+00$ \\
480. & 0.17 & $2.00 \mathrm{E}+07$ & $3.47 \mathrm{E}+06$ & $0.00 \mathrm{E}+00$ \\
780. & 0.17 & $2.00 \mathrm{E}+07$ & $3.47 \mathrm{E}+06$ & $0.00 \mathrm{E}+00$ \\
1115. & 0.17 & $2.00 \mathrm{E}+07$ & $3.47 \mathrm{E}+06$ & $0.00 \mathrm{E}+00$ \\
1125. & $0.00 \mathrm{E}+00$ & $2.00 \mathrm{E}+07$ & $0.00 \mathrm{E}+00$ & $0.00 \mathrm{E}+00$
\end{tabular}

Time $=0.0$ seconds .

\begin{tabular}{cccccccc} 
Compartment & $\begin{array}{l}\text { Upper } \\
\text { Temp. } \\
(\mathrm{K})\end{array}$ & $\begin{array}{l}\text { Lower } \\
\text { Temp. } \\
(\mathrm{K})\end{array}$ & $\begin{array}{l}\text { Inter. } \\
\text { Height } \\
(\mathrm{m})\end{array}$ & $\begin{array}{l}\text { Pyrol } \\
\text { Rate } \\
(\mathrm{kg} / \mathrm{s})\end{array}$ & $\begin{array}{l}\text { Fire } \\
\text { Size } \\
(\mathrm{W})\end{array}$ & $\begin{array}{l}\text { Pressure } \\
(\mathrm{Pa})\end{array}$ & $\begin{array}{l}\text { Ambient } \\
\text { Target } \\
\left(\mathrm{W} / \mathrm{m}^{-2} 2\right)\end{array}$ \\
\hdashline $\begin{array}{c}1 \\
\text { Outside }\end{array}$ & 311.0 & 311.0 & 17. & $0.000 \mathrm{E}+00$ & $0.000 \mathrm{0}+00-0.440$ & $0.000 \mathrm{E}+00$ \\
\end{tabular}

Time $=120.0$ seconds .

\begin{tabular}{cccccccc} 
Compartment & $\begin{array}{l}\text { Upper } \\
\text { Temp. } \\
(\mathrm{K})\end{array}$ & $\begin{array}{l}\text { Lower } \\
\text { Temp. }\end{array}$ & $\begin{array}{l}\text { Inter. } \\
\text { Height } \\
(\mathrm{m})\end{array}$ & $\begin{array}{l}\text { Pyrol } \\
\text { Rate } \\
(\mathrm{kg} / \mathrm{s})\end{array}$ & $\begin{array}{l}\text { Fire } \\
\text { Size } \\
(\mathrm{W})\end{array}$ & $\begin{array}{l}\text { Pressure } \\
(\mathrm{Pa})\end{array}$ & $\begin{array}{l}\text { Ambient } \\
\text { Target } \\
\left(\mathrm{W} / \mathrm{m}^{\circ} 2\right)\end{array}$ \\
\hline $\begin{array}{c}1 \\
\text { Outside }\end{array}$ & 356.1 & 311.3 & 15. & 0.174 & $3.469 \mathrm{E}+06$ & 6.53 & 382. \\
\end{tabular}

Time $=240.0$ seconds .

$\begin{array}{clllll}\text { Compartment } & \text { Upper Lower Inter. Pyrol Fire } & \text { Pressure Ambient } \\ & \text { Temp. } & \text { Temp. Height Rate } & \text { Size } & & \text { Target }\end{array}$

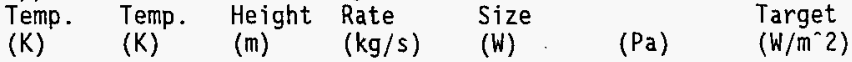

\begin{tabular}{|c|c|c|c|c|c|c|c|}
\hline$\stackrel{1}{\text { Outside }}$ & 359.1 & 312.0 & 14. & 0.174 & $\begin{array}{l}3.469 E+06 \\
0.000 E+00\end{array}$ & 5.25 & 413. \\
\hline
\end{tabular}

Time $=360.0$ seconds .

$\begin{array}{llllllll}\text { Compartment } & \text { Upper } & \text { Lower } & \text { Inter. Pyrol } & \text { Fire } & \text { Pressure Ambient } \\ & \begin{array}{llll}\text { Temp. } \\ \text { (K) }\end{array} & \text { Temp. } & \text { Height } & \text { Rate } & \text { Size } & & \text { Target } \\ & (\mathrm{K}) & (\mathrm{m}) & (\mathrm{kg} / \mathrm{s}) & (\mathrm{W}) & (\mathrm{Pa}) & \left(\mathrm{W} / \mathrm{m}^{\wedge} 2\right)\end{array}$




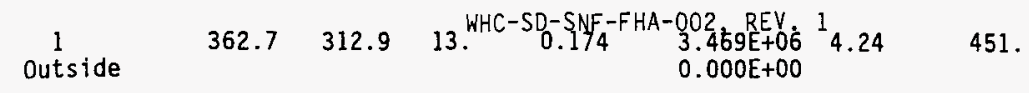

Time $=480.0$ seconds.

\begin{tabular}{|c|c|c|c|c|c|c|c|}
\hline Compartment & $\begin{array}{l}\text { Upper } \\
\text { Temp. } \\
\text { (K) }\end{array}$ & $\begin{array}{l}\text { Lower } \\
\text { Temp. } \\
\text { (K) }\end{array}$ & $\begin{array}{l}\text { Inter. } \\
\text { Height } \\
\text { (m) }\end{array}$ & $\begin{array}{l}\text { Pyrol } \\
\text { Rate } \\
(\mathrm{kg} / \mathrm{s})\end{array}$ & $\begin{array}{l}\text { Fire } \\
\text { Size } \\
(W)\end{array}$ & $\begin{array}{l}\text { Pressure } \\
(\mathrm{Pa})\end{array}$ & $\begin{array}{l}\text { Ambient } \\
\text { Target } \\
\left(\mathrm{W} / \mathrm{m}^{-2} \mathrm{2}\right)\end{array}$ \\
\hline$\stackrel{1}{\text { Outside }}$ & 365.9 & 314.0 & 12. & 0.174 & $\begin{array}{l}3.468 E+06 \\
0.000 E+00\end{array}$ & 3.38 & 486 . \\
\hline
\end{tabular}

Time $=600.0$ seconds.

\begin{tabular}{clllllll} 
Compartment & $\begin{array}{l}\text { Upper } \\
\text { Temp. } \\
(\mathrm{K})\end{array}$ & $\begin{array}{l}\text { Lower } \\
\text { Temp. } \\
(\mathrm{K})\end{array}$ & $\begin{array}{l}\text { Inter. } \\
\text { Height } \\
(\mathrm{m})\end{array}$ & $\begin{array}{l}\text { Pyrol } \\
\text { Rate } \\
(\mathrm{kg} / \mathrm{s})\end{array}$ & $\begin{array}{l}\text { Fire } \\
\text { Size } \\
(\mathrm{W})\end{array}$ & $\begin{array}{l}\text { Pressure } \\
(\mathrm{Pa})\end{array}$ & $\begin{array}{l}\text { Ambient } \\
\text { Target } \\
\left(\mathrm{W} / \mathrm{m}^{\wedge} 2\right)\end{array}$ \\
\hline $\begin{array}{c}1 \\
\text { Outside }\end{array}$ & 368.3 & 315.2 & 12. & 0.174 & $3.468 \mathrm{E}+06$ & 2.77 & 513. \\
\end{tabular}

Time $=720.0$ seconds .

\begin{tabular}{|c|c|c|c|c|c|c|c|}
\hline Compartment & $\begin{array}{l}\text { Upper } \\
\text { Temp. } \\
\text { (K) }\end{array}$ & $\begin{array}{l}\text { Lower } \\
\text { Temp. } \\
\text { (K) }\end{array}$ & $\begin{array}{l}\text { Inter, } \\
\text { Height } \\
(\mathrm{m})\end{array}$ & $\begin{array}{l}\text { Pyrol } \\
\text { Rate } \\
(\mathrm{kg} / \mathrm{s})\end{array}$ & $\begin{array}{l}\text { Fire } \\
\text { Size } \\
(W)\end{array}$ & $\begin{array}{l}\text { Pressure } \\
\text { (Pa) }\end{array}$ & $\begin{array}{l}\text { Ambient } \\
\text { Target } \\
\left(W / m^{-2}\right)\end{array}$ \\
\hline$\stackrel{1}{\text { Outside }}$ & 370.3 & 316.4 & 11. & 0.174 & $\begin{array}{l}3.468 \mathrm{E}+06 \\
0.000 \mathrm{E}+00\end{array}$ & 2.24 & 536. \\
\hline
\end{tabular}

Time $=840.0$ seconds.

\begin{tabular}{cccccccc} 
Compartment & $\begin{array}{l}\text { Upper } \\
\text { Temp. } \\
(\mathrm{K})\end{array}$ & $\begin{array}{l}\text { Lower } \\
\text { Temp. } \\
(\mathrm{K})\end{array}$ & $\begin{array}{l}\text { Inter. } \\
\text { Height } \\
(\mathrm{m})\end{array}$ & $\begin{array}{l}\text { Pyrol } \\
\text { Rate } \\
(\mathrm{kg} / \mathrm{s})\end{array}$ & $\begin{array}{l}\text { Fire } \\
\text { Size } \\
(\mathrm{W})\end{array}$ & $\begin{array}{l}\text { Pressure } \\
(\mathrm{Pa})\end{array}$ & $\begin{array}{l}\text { Ambient } \\
\text { Target } \\
\left(\mathrm{W} / \mathrm{m}^{-2} 2\right)\end{array}$ \\
\hline $\begin{array}{c}1 \\
\text { Outside }\end{array}$ & 372.0 & 317.8 & 11. & 0.174 & $\begin{array}{l}3.468 \mathrm{E}+06 \\
0.000 \mathrm{E}+00\end{array}$ & 1.76 & 556.
\end{tabular}

Time $=960.0$ seconds .

\begin{tabular}{cccccccc} 
Compartment & $\begin{array}{l}\text { Upper } \\
\text { Temp. } \\
(\mathrm{K})\end{array}$ & $\begin{array}{l}\text { Lower } \\
\text { Temp. } \\
(\mathrm{K})\end{array}$ & $\begin{array}{l}\text { Inter. } \\
\text { Height } \\
(\mathrm{m})\end{array}$ & $\begin{array}{l}\text { Pyrol } \\
\text { Rate } \\
(\mathrm{kg} / \mathrm{s})\end{array}$ & $\begin{array}{l}\text { Fire } \\
\text { Size } \\
(\mathrm{W})\end{array}$ & $\begin{array}{l}\text { Pressure } \\
(\mathrm{Pa})\end{array}$ & $\begin{array}{l}\text { Ambient } \\
\text { Target } \\
\left(\mathrm{W} / \mathrm{m}^{-2} 2\right)\end{array}$ \\
\hline $\begin{array}{c}1 \\
\text { Outside }\end{array}$ & 373.5 & 319.1 & 10. & 0.174 & $\begin{array}{l}3.468 E+06 \\
0.000 E+00\end{array}$ & 1.34 & 573.
\end{tabular}


WHC-SD-SNF-FHA-002, REV. 1

Time $=1080.0$ seconds .

\begin{tabular}{cccccccc} 
Compartment & $\begin{array}{l}\text { Upper } \\
\text { Temp. } \\
(\mathrm{K})\end{array}$ & $\begin{array}{l}\text { Lower } \\
\text { Temp. } \\
(\mathrm{K})\end{array}$ & $\begin{array}{l}\text { Inter. } \\
\text { Height } \\
(\mathrm{m})\end{array}$ & $\begin{array}{l}\text { Pyrol } \\
\text { Rate } \\
(\mathrm{kg} / \mathrm{s})\end{array}$ & $\begin{array}{l}\text { Fire } \\
\text { Size } \\
(\mathrm{W})\end{array}$ & $\begin{array}{l}\text { Pressure } \\
(\mathrm{Pa})\end{array}$ & $\begin{array}{l}\text { Ambient } \\
\text { Target } \\
\left(\mathrm{W} / \mathrm{m}^{\wedge} 2\right)\end{array}$ \\
\hline $\begin{array}{c}1 \\
\text { Outside }\end{array}$ & 374.9 & 320.4 & 10.0 & 0.174 & $\begin{array}{l}3.467 \mathrm{E}+06 \\
0.962\end{array}$ & 590. \\
\end{tabular}


FASTLite

Developed by:
Fire Estimation Tools

Building and Fire Research Laboratory Gaithersburg, MD 20899

Licensed to:

Project Reference:

Project:

Calculation: Ceiling Plume Temperature

MHM CABLE BURN

Date of Calculation: 19 June 1996

This formula estimates the gas temperature inside the plume impingement zone near the ceiling in a room with a fire. The calculated temeprature is conservative on the high side. It is recommended that this computation be used when estimating the damaging impact of ceiling hets. These values are not recommended when estimating device actuation time.

Unless the room has ceiling vents to remove the hot gases that accumulate at the ceiling, a hot gas layer will eventually build up sufficiently to cause the temperature to rise above that predicted by this procedure. The procedure reports that approximate time when this rise starts.

Fire size: $3.469 \mathrm{E}+006 \mathrm{~W}$

Fire location: In a corner

Ceiling height: $16.764 \mathrm{~m}$ above base of the fire Ambient temperature: $310.97 \mathrm{~K}$

Estimated ceiling plume temperature: $4.3 \mathrm{E}+002 \mathrm{~K}$

Estimated time to hot gas layer formation: $5.3 \mathrm{E}+002 \mathrm{~s}$ 
WHC-SD-SNF-FHA-002, REV. 1

CALCULATION 3, TENT FIRE. This evaluation was performed to determine the damage potential from the MHM crane cable insulation fire on the structure.

The tent is valued at approximately $\$ 20,000$ and assumed to be totally lost in a tent fire. Cleanup from a tent fire would add an estimated $\$ 5,000$. These losses by themselves are well below the $\$ 1$ million criterion that would require an automatic suppression system. These calculations were required to determine whether additional losses from damage to the structure could increase the total losses above \$1 million.

The MCO Service Station tent is approximately $2.9 \mathrm{~m}$ high by $5.8 \mathrm{~m}$ by $7.3 \mathrm{~m}$. A distance of approximately 13.7 m exists between the top of the tent and the structure ceiling.

$118 \mathrm{~m}^{2}\left(142 \mathrm{yd}^{2}\right)$ total surface area

$0.614 \mathrm{~kg} / \mathrm{m}^{2}$ (18 oz/yd $\left.\mathrm{yd}^{2}\right)$ density (from vendor)

$30 \mathrm{~kJ} / \mathrm{g}$ potential heat value (ball park estimate for vinyl/nylon)

$1010 \mathrm{~kW} / \mathrm{m}^{2}$ heat release rate estimate for polyethylene

$1010 \mathrm{~kW} / \mathrm{m}^{2} \times 118 \mathrm{~m}^{2} \div 10=11,918 \mathrm{~kW}(11,918 \mathrm{~kJ} / \mathrm{s})$ maximum burn rate. Due to the fire retardant treatment of the material, only $10 \%$ of the surface was assumed to be burning at any one time. The material has undergone the NFPA 701 - Large Scale test.

$118 \mathrm{~m}^{2} \times 0.614 \mathrm{~kg} / \mathrm{m}^{2} \times 30,000 \mathrm{~kJ} / \mathrm{kg} \div 11,918 \mathrm{~kJ} / \mathrm{s}=182$ seconds burn duration assuming on $1 y 10 \%$ of the surface is involved at any one time.

The data was inputted to the FASTLite fire model program to determine if the critical upper layer temperature would approach the critical temperature for structural steel. The critical temperature is described as the temperature at which collapse is impending and approximated at $811^{\circ} \mathrm{K}\left(1000^{\circ} \mathrm{F}\right)$. The yield strength and modulus of elasticity of steel at these temperatures decreased to about $60 \%$ of the value at normal room temperature. The American Institute for Steel Construction Specification for the Design, Fabrication and Erection of Structural Steel Buildings limits the maximum permissible design stress to approximately $60 \%$ of the yield strength.

The material will not self-sustain a fire and a continuous flame source is not anticipated to exist in the Operating Area. However, even under the conditions where almost $12 \mathrm{~m}^{2}$ of material is burning at any time, the program showed that the upper layer temperature initially reached a temperature of about $540^{\circ} \mathrm{K}\left(513^{\circ} \mathrm{F}\right)$ then steadily declined to about $480^{\circ} \mathrm{K}\left(405^{\circ} \mathrm{F}\right)$. A smaller fire with a longer duration resulted in a lower maximum upper layer temperature.

The plume temperature was also calculated to determine if the roofing material, which includes a sandwiched polystyrene material, would become involved. The ignition temperature of polystyrene is listed at $846^{\circ} \mathrm{K}$ per Table A-6 of the Fire Protection Handbook, Seventeenth Edition. The FASTLite Ceiling Plume Temperature calculation estimated a temperature of $480^{\circ} \mathrm{K}\left(405^{\circ} \mathrm{F}\right)$. 
WHC-SD-SNF-FHA-002, REV. 1

Due to the fire retardant treatment of the tent material and the relatively small fuel load, no damage to the structure is predicted. 


$$
\text { WHC-SD-SNF-FHA-002, REV . } 1
$$

CFAST Version 2.2.1 User Defined Base Case

Data file is TENTI.DAT (Checksum 00000000)

OVERVIEW

Compartments Doors, ... Ceil. Vents, ... MV Connects

TENT BURN

$\begin{array}{llll}1 & 0 & 0\end{array}$

\begin{tabular}{|c|c|c|c|}
\hline $\begin{array}{l}\text { Simulation } \\
\text { Time } \\
\text { (s) }\end{array}$ & $\begin{array}{l}\text { Print } \\
\text { Interval } \\
\text { (s) }\end{array}$ & $\begin{array}{l}\text { History } \\
\text { Interval } \\
\text { (s) }\end{array}$ & $\begin{array}{l}\text { Restart } \\
\text { Interval } \\
\text { (s) }\end{array}$ \\
\hline 200 & 20 & 10 & 0 \\
\hline
\end{tabular}

Ceiling jet is on for all

COMPARTMENTS

Compartment Width Depth Height Ceiling Floor

\begin{tabular}{cccccc} 
& & & Height & $\begin{array}{l}\text { Height } \\
(\mathrm{m})\end{array}$ \\
\hline 1 & 62.48 & 41.15 & 16.76 & 16.76 & 0.00
\end{tabular}

VENT CONNECTIONS

Horizontal Natural Flow Connections (Doors, Windows, ...)

\begin{tabular}{llcccc}
$\begin{array}{l}\text { From } \\
\text { Compartment }\end{array}$ & $\begin{array}{l}\text { To } \\
\text { Compartment }\end{array}$ & $\begin{array}{l}\text { Vent } \\
\text { Number } \\
(m)\end{array}$ & $\begin{array}{c}\text { Width } \\
(m)\end{array}$ & $\begin{array}{l}\text { Sill } \\
\text { Height } \\
(m)\end{array}$ & $\begin{array}{l}\text { Soffit } \\
\text { Height } \\
(m)\end{array}$ \\
\hline 1 & Outside & 1 & 0.91 & 0.00 & 2.13
\end{tabular}

There are no vertical natural flow connections

THERMAL PROPERTIES

\begin{tabular}{llc} 
Compartment Ceiling & Wall & Floor \\
\hline 1 & STEELSHT & STEELSHT \\
CONCRETE
\end{tabular}

Thermal data base used: THERMAL.DF

$\begin{array}{lccclc}\text { Name } & \text { Conductivity } & \text { Specific heat } & \text { Density } & \text { Thickness } & \text { Emissivity } \\ \text { STEELSHT } & 48.0 & 559 . & 7.854 \mathrm{E}+03 & 1.500 \mathrm{E}-03 & 0.900 \\ \text { CONCRETE } & 1.75 & 1.000 \mathrm{E}+03 & 2.200 \mathrm{E}+03 & 0.150 & 0.940\end{array}$




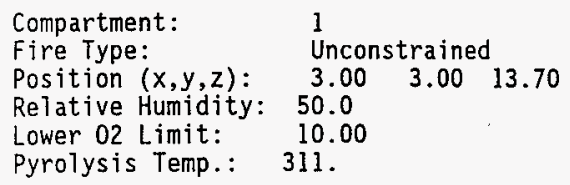

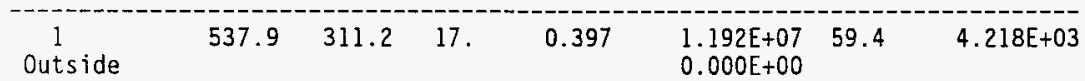

Time $=40.0$ seconds .

Compartment Upper Lower Inter. Pyrol Fire Pressure Ambient Temp. Temp. Height Rate Size Target

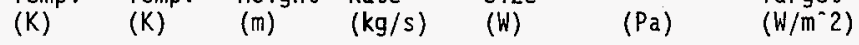

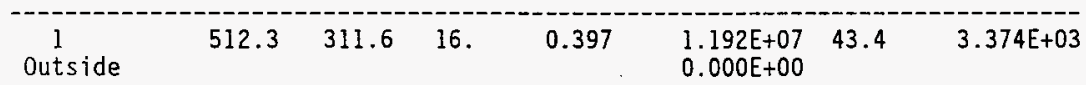

Time $=60.0$ seconds .

$\begin{array}{llllllll}\text { Compartment } & \begin{array}{l}\text { Upper } \\ \text { Temp. } \\ (\mathrm{K})\end{array} & \begin{array}{l}\text { Lower } \\ \text { Temp. } \\ (\mathrm{K})\end{array} & \begin{array}{l}\text { Inter. } \\ \text { Height } \\ (\mathrm{m})\end{array} & \begin{array}{l}\text { Pyrol } \\ \text { Rate } \\ (\mathrm{kg} / \mathrm{s})\end{array} & \begin{array}{l}\text { Fire } \\ \text { Size } \\ (\mathrm{W})\end{array} & \begin{array}{l}\text { Pressure Ambient } \\ (\mathrm{Pa})\end{array} & \begin{array}{l}\text { Target } \\ \left(\mathrm{W} / \mathrm{m}^{\wedge} 2\right)\end{array} \\ & & & \end{array}$



$\stackrel{1}{\text { Outside }}$
$499.2 \quad 312.0 \quad 16$.
WHC-SD-SNF-FHA-002, REV. 1
$0.397 \quad 1.192 \mathrm{E}+07$
$40.0 \quad 2.991 E+03$

Time $=80.0$ seconds.

\begin{tabular}{cccccccc} 
Compartment & $\begin{array}{l}\text { Upper } \\
\text { Temp. } \\
(\mathrm{K})\end{array}$ & $\begin{array}{l}\text { Lower } \\
\text { Temp. } \\
(\mathrm{K})\end{array}$ & $\begin{array}{l}\text { Inter. } \\
\text { Height } \\
(\mathrm{m})\end{array}$ & $\begin{array}{l}\text { Pyrol } \\
\text { Rate } \\
(\mathrm{kg} / \mathrm{s})\end{array}$ & $\begin{array}{l}\text { Fire } \\
\text { Size } \\
(\mathrm{W})\end{array}$ & $\begin{array}{l}\text { Pressure } \\
(\mathrm{Pa})\end{array}$ & $\begin{array}{l}\text { Ambient } \\
\text { Target } \\
\left(\mathrm{W} / \mathrm{m}^{2} 2\right)\end{array}$ \\
\hline $\begin{array}{c}1 \\
\text { Outside }\end{array}$ & 492.0 & 312.5 & 16. & 0.397 & $\begin{array}{l}1.192 \mathrm{E}+07 \\
0.000 \mathrm{E}+00\end{array}$ & 38.6 & $2.791 \mathrm{E}+03$ \\
& & & & & & &
\end{tabular}

Time $=100.0$ seconds .

Compartment Upper Lower Inter. Pyrol Fire Pressure Ambient Temp. Temp. Height Rate Size Target

$\begin{array}{llllll}(\mathrm{K}) & (\mathrm{K}) \quad(\mathrm{m}) & (\mathrm{kg} / \mathrm{s}) & (\mathrm{W}) & (\mathrm{Pa}) & \left(\mathrm{W} / \mathrm{m}^{\wedge} 2\right)\end{array}$

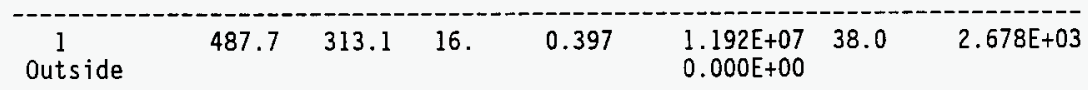

Time $=120.0$ seconds .

Compartment Upper Lower Inter. Pyrol Fire Pressure Ambient Temp. Temp. Height Rate Size Target
(K)
(K)
(m) $\quad(\mathrm{kg} / \mathrm{s})$
(W)
$(\mathrm{Pa})$
$\left(W / m^{\wedge} 2\right)$

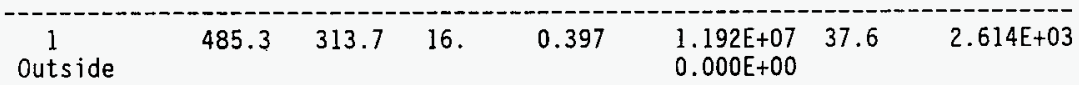

Time $=140.0$ seconds.

\begin{tabular}{cccccccc} 
Compartment & $\begin{array}{l}\text { Upper } \\
\text { Temp. } \\
(\mathrm{K})\end{array}$ & $\begin{array}{l}\text { Lower } \\
\text { Temp. } \\
(\mathrm{K})\end{array}$ & $\begin{array}{l}\text { Inter. } \\
\text { Height } \\
(\mathrm{m})\end{array}$ & $\begin{array}{l}\text { Pyrol } \\
\text { Rate } \\
(\mathrm{kg} / \mathrm{s})\end{array}$ & $\begin{array}{l}\text { Fire } \\
\text { Size } \\
(\mathrm{W})\end{array}$ & $\begin{array}{l}\text { Pressure } \\
(\mathrm{Pa})\end{array}$ & $\begin{array}{l}\text { Ambient } \\
\text { Target } \\
\left(\mathrm{W} / \mathrm{m}^{2} 2\right)\end{array}$ \\
\hline $\begin{array}{c}1 \\
\text { Outside }\end{array}$ & 483.9 & 314.3 & 16. & 0.397 & $\begin{array}{l}1.192 \mathrm{E}+07 \\
0.000 \mathrm{E}+00\end{array}$ & 37.2 & $2.580 \mathrm{E}+03$ \\
& & & & & & &
\end{tabular}

Time $=160.0$ seconds .

Compartment Upper Lower Inter. Pyrol Fire Pressure Ambient Temp. Temp. Height Rate Size Target

\begin{tabular}{|c|c|c|c|c|c|c|c|}
\hline & (K) & (K) & $(m)$ & $(\mathrm{kg} / \mathrm{s})$ & (W) & $(\mathrm{Pa})$ & $\left(W / m^{\wedge} 2\right)$ \\
\hline $\begin{array}{l}1 \\
\text { Outside }\end{array}$ & 483.4 & 314.9 & 15. & 0.397 & $\begin{array}{l}1.192 \mathrm{E}+07 \\
0.000 \mathrm{E}+00\end{array}$ & 36.8 & $2.565 E+03$ \\
\hline
\end{tabular}


WHC-SD-SNF-FHA-002, REV. 1

\begin{tabular}{cccccccc} 
Compartment & $\begin{array}{l}\text { Upper } \\
\text { Temp. } \\
(\mathrm{K})\end{array}$ & $\begin{array}{l}\text { Lower } \\
\text { Temp. } \\
(\mathrm{K})\end{array}$ & $\begin{array}{l}\text { Inter. } \\
\text { Height } \\
(\mathrm{m})\end{array}$ & $\begin{array}{l}\text { Pyrol } \\
\text { Rate } \\
(\mathrm{kg} / \mathrm{s})\end{array}$ & $\begin{array}{l}\text { Fire } \\
\text { Size } \\
(\mathrm{W})\end{array}$ & $\begin{array}{l}\text { Pressure } \\
(\mathrm{Pa})\end{array}$ & $\begin{array}{l}\text { Ambient } \\
\text { Target } \\
\left(\mathrm{W} / \mathrm{m}^{\wedge} 2\right)\end{array}$ \\
\hline $\begin{array}{c}1 \\
\text { Outside }\end{array}$ & 483.3 & 315.6 & 15. & 0.397 & $\begin{array}{l}1.192 \mathrm{E}+07 \\
0.000 \mathrm{E}+00\end{array}$ & 36.2 & $2.563 \mathrm{E}+03$
\end{tabular}


FASTLite

Developed by:
Fire Estimation Tools

Building and Fire Research Laboratory Gaithersburg, MD 20899

Licensed to:

Project Reference:

Project:

Calculation: $\quad$ Ceiling Plume Temperature

Date of Calculation: 19 June 1996

TENT BURN

This formula estimates the gas temperature inside the plume impingement zone near the ceiling in a room with a fire. The calculated temeprature is conservative on the high side. It is recommended that this computation be used when estimating the damaging impact of ceiling hets. These values are not recommended when estimating device actuation time.

Unless the room has ceiling vents to remove the hot gases that accumulate at the ceiling, a hot gas layer will eventually build up sufficiently to cause the temperature to rise above that predicted by this procedure. The procedure reports that approximate time when this rise starts.

Fire size: $1.1918 \mathrm{E}+007 \mathrm{~W}$

Fire location: Near a wall

Ceiling height: $16.764 \mathrm{~m}$ above base of the fire

Ambient temperature: $310.97 \mathrm{~K}$

Estimated ceiling plume temperature: $4.8 \mathrm{E}+002 \mathrm{~K}$

Estimated time to hot gas layer formation: $3.5 \mathrm{E}+002 \mathrm{~s}$ 